
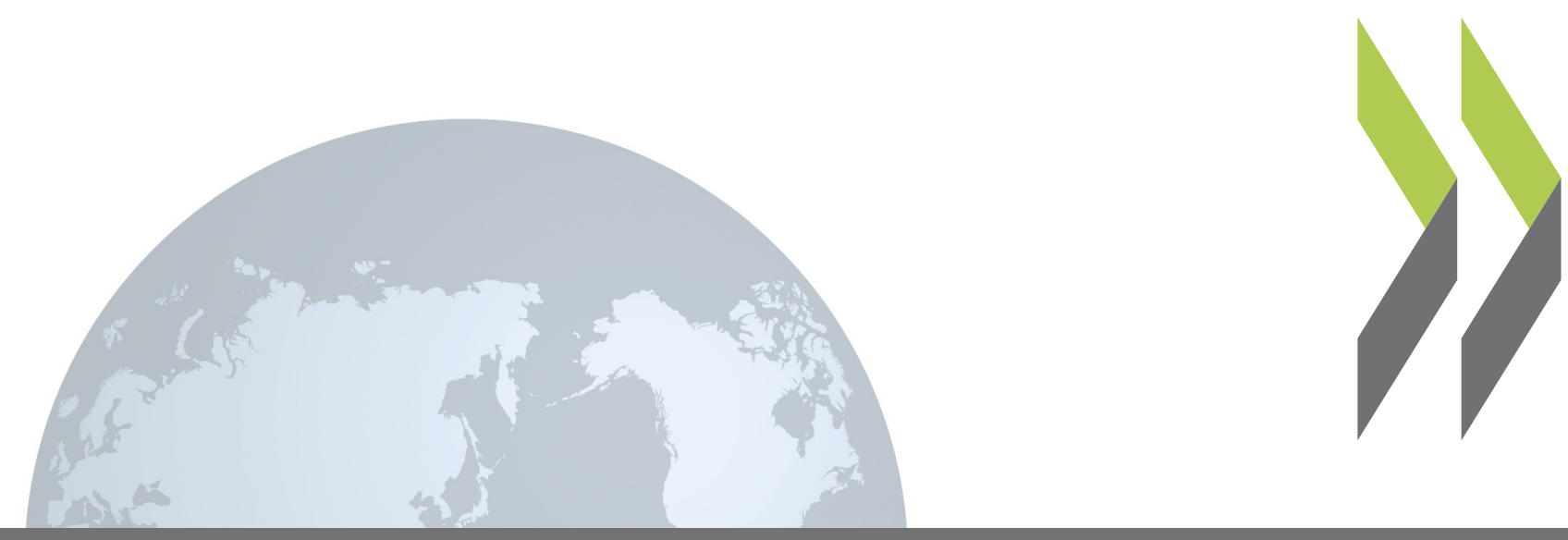

OECD Corporate Governance Working Papers No. 9

\title{
Disclosure of Beneficial Ownership and Control
} in Indonesia: Legislative and Regulatory Policy Options for Sustainable Capital Markets

\section{Fianna Jurdant}




\section{OECD CORPORATE GOVERNANCE WORKING PAPERS}

OECD Corporate Governance Working Papers provide timely analysis and information on national and international corporate governance issues and developments, including state ownership and privatisation policies. The working paper series is designed to make select studies by the OECD Corporate Governance Committee, OECD staff members and outside consultants available to a broad audience.

The papers are generally available only in their original language English or French with a summary in the other if available.

The opinions expressed in these papers are the sole responsibility of the author(s) and do not necessarily reflect those of the OECD or the governments of its member countries, unless otherwise noted.

Comment on the series is welcome, and should be sent to either corporate.affairs@oecd.org or the Corporate Affairs Division, OECD, 2, rue André Pascal, 75775 PARIS CEDEX 16, France.

OECD CORPORATE GOVERNANCE WORKING PAPERS

are published on www.oecd.org/daf/corporateaffairs/wp

This document and any map included herein are without prejudice to the status of or sovereignty over any territory, to the delimitation of international frontiers and boundaries and to the name of any territory, city or area.

(C) OECD 2013

Applications for permission to reproduce or translate all or part of this material should be made to: OECD Publishing, rights@oecd.org or by fax 33145249930. 


\section{Abstract \\ DISCLOSURE OF BENEFICIAL OWNERSHIP AND CONTROL IN INDONESIA \\ LEGISLATIVE AND REGULATORY POLICY OPTIONS FOR SUSTAINABLE CAPITAL MARKETS}

By Fianna Jurdant

A good corporate governance framework should combine transparency, accountability and integrity and this requires knowledge of beneficial ownership. The protection of minority investors and other stakeholder protection will be challenging without access to reliable information about the ownership, including the identity of the controlling owners, and control structures of listed companies. This report assesses the costs, benefits and practicalities of different approaches, suggesting policy options to better identify ultimate beneficial ownership in Indonesia.

This report was requested by the Capital Market and Financial Institution Supervisory Agency in Indonesia, Bapepam-LK, in the context of the OECD-Indonesia corporate governance policy dialogue launched in 2011. The objective is to support policy makers and regulators in their efforts to enhance disclosure and enforcement of beneficial ownership and control as part of overall efforts to improve corporate governance standards and practices in Indonesia.

JEL Classification: G30, G32, K22, K42

Keywords: beneficial ownership, control-enhancing mechanisms, corporate governance, disclosure, inside blockholders, money laundering, outside blockholders, private enforcement, public enforcement, shareholders.

This report was prepared by Fianna Jurdant, Corporate Affairs Division, OECD Directorate for Financial and Enterprise Affairs, with input from Erik Vermeulen and Rainer Geiger, acting as consultants for the OECD, and FATF. The report benefitted from important contributions by Bapepam-LK, in particular Etty Retno Wulandari and Djonieri, and reviews of earlier drafts by participants in the OECD-Indonesia Programme on Corporate Governance as well as consultations with other government agencies and stakeholders in Indonesia. The preparation of the report received financial support from Japan. 


\section{FOREWORD}

We learned from the global financial crisis that corporate governance does matter. Weak corporate governance practices have been identified as one of the causes of the crisis. The Indonesian authorities share with other important players in the global economy, a special responsibility to ensure financial stability. Bapepam-LK, Indonesia's Capital Market and Financial Institution Supervisory Agency, is committed to enhancing corporate governance practices in Indonesia as part of financial stability efforts.

As a G20 member, Indonesia agreed to be assessed under the Financial Sector Assessment Program (FSAP), which includes a Report on the Observance of Standards and Codes (ROSC) on Corporate Governance. The ROSC on Corporate Governance assesses a country's legal and regulatory framework, practices and compliance of listed companies against the OECD Principles of Corporate Governance. Through this assessment, weaknesses that may contribute to a country's economic and financial vulnerability and areas for improvement are identified. One of the key findings of the 2010 ROSC assessment is that Indonesia should improve the regulatory framework of the disclosure of beneficial ownership and control. In response to this recommendation, Bapepam-LK requested that the OECD undertake an in-depth review of this issue and provide policy options.

The report, "Disclosure of Beneficial Ownership and Control in Indonesia", is the result of this work. It is one of the most important deliverables of the Indonesia-OECD Programme on Corporate Governance. Based upon extensive consultation in 2011 and 2012 with Bapepam-LK, the Indonesian Stock Exchange, Central Bank of Indonesia and other professional and official institutions, this report provides recommendations for improvement, for example, that BapepamLK align its reform initiatives regarding the disclosure of beneficial ownership and control structures with those of tax regulators and other supervisory authorities.

The report also recommends uniform definitions, minimum standards and reporting, information sharing amongst relevant authorities and enforcement of disclosure requirements for beneficial owners. By implementing the recommendations of this report, it is expected that Indonesia's listed companies will enhance their own transparency and contribute to better compliance with disclosure rules and regulations.

The Indonesia-OECD Programme on Corporate Governance offers policymakers a comparative basis for designing policy options and implementation of the OECD Principles of Corporate Governance. Forthcoming issues to be examined include board nomination and election.

Bapepam-LK would like to express its highest appreciation to the OECD for preparing this report and providing invaluable policy and technical support during the process. We hope that this report will serve as a cornerstone for the implementation of good corporate governance in Indonesia. The OECD would like to commend Bapepam-LK for its commitment to tackle this challenging issue. This report will serve as a valuable reference globally, including in future work by the OECD Corporate Governance Committee and the OECD-Asian Roundtable on Corporate Governance.

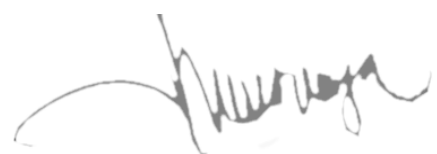

Ngalim Sawega Chairman of Bapepam-LK

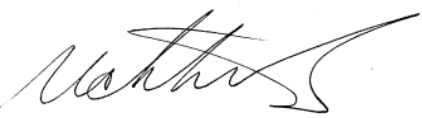

Richard Boucher Deputy Secretary General, OECD 


\section{TABLE OF CONTENTS}

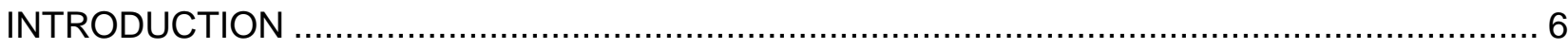

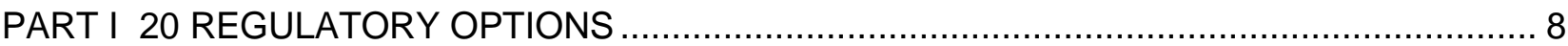

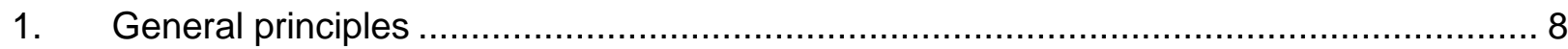

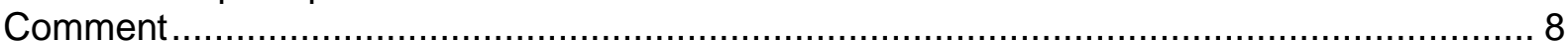

2. Disclosure of beneficial ownership and control in listed companies ........................... 9

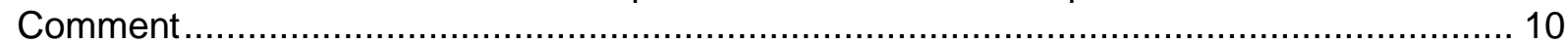

3. Information about beneficial ownership and control ............................................ 11

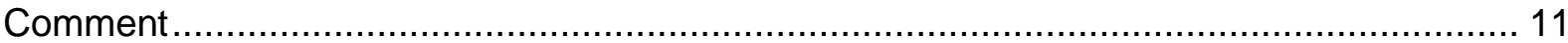

4. Enforcement

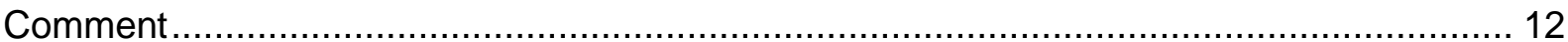

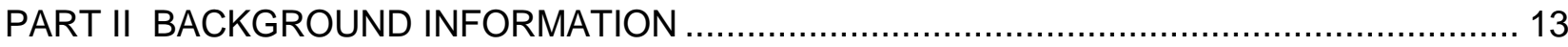

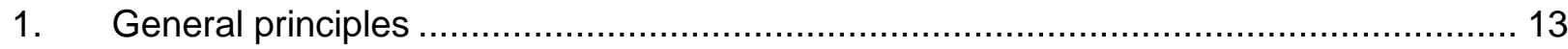

$1.1 \quad$ Why disclosure of beneficial ownership and control? .......................................... 13

1.2 Potential costs of disclosure rules and regulations ............................................ 14

1.3 Towards a culture of compliance with beneficial ownership and control disclosure

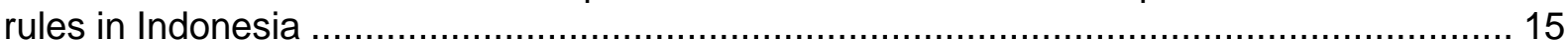

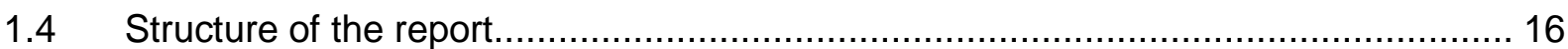

2. Disclosure of beneficial ownership and control in listed companies .......................... 17

2.1 Initial public offerings and listed companies: Regulation or deregulation?................ 17

2.2 Brazil's Novo Mercado: Stringent corporate governance and disclosure rules .......... 18

2.3 Malaysia's reforms: From stringent towards proportionate disclosure rules .............. 22

2.4 The United States: Proportionality and flexibility in disclosure of beneficial ownership23

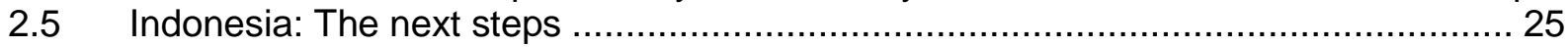

3. Information about beneficial ownership and control ............................................. 30

3.1 Central securities depositories, custodians and intermediaries .............................. 30

3.2 Disclosure of beneficial ownership of corporate vehicles ..................................... 31

3.3 Intra-governmental and cross-border collaboration and information sharing ............. 35

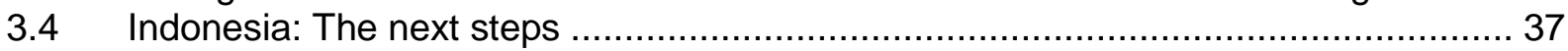

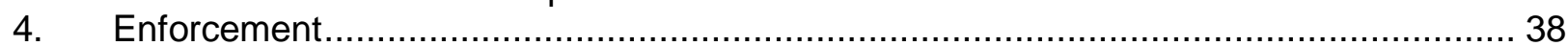

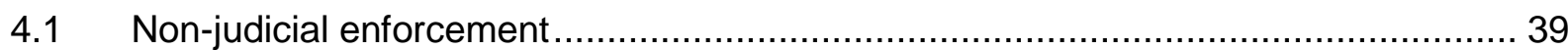

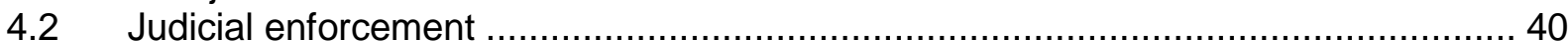

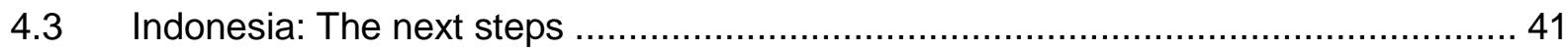

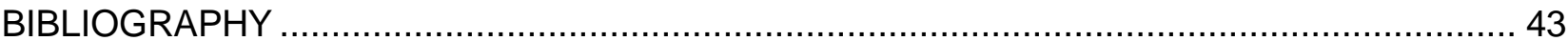




\section{INTRODUCTION}

This report was requested by Bapepam-LK, the Capital Market and Financial Institution Supervisory Agency in Indonesia, in the context of the OECD-Indonesia policy dialogue on corporate governance launched in 2011. ${ }^{1}$ The objective is to support policy makers and regulators in their efforts to enhance disclosure and enforcement of beneficial ownership and control as part of overall efforts to improve corporate governance standards and practices in Indonesia. This report benefits from a background paper that provides a comparative analysis of how disclosure of beneficial ownership is handled by other jurisdictions. It also benefits from meetings in October 2011 and February 2012 with Indonesian officials and practitioners as well as their counterparts from other jurisdictions.

Corporate governance is important for the efficient functioning of markets and enterprises, in accordance with the overall goals of communities and societies. An effective and sustainable corporate governance infrastructure helps promote investor confidence and assists firms in meeting investors' expectations. It also helps regulators to deal effectively with systemic issues and stakeholders to play their roles within the company. It is based on accountability and integrity of corporate boards. The financial crisis has highlighted these issues, where policy makers and stakeholders once more challenged the absence of a corporate governance infrastructure that adequately protects shareholders and other stakeholders in listed companies. ${ }^{2}$

Investor confidence in financial markets depends in large part on the existence of an accurate disclosure regime that provides transparency in the beneficial ownership and control structures of publicly listed companies. This is particularly true for corporate governance systems that are characterised by concentrated ownership. On the one hand, large investors with significant voting and cash-flow rights may encourage long-term growth and firm performance. On the other hand, however, controlling beneficial owners with large voting blocks may have incentives to divert corporate assets and opportunities for personal gain at the expense of minority investors.

This report does not only deal with minority shareholder protection, it also takes the interests of other stakeholders and society as a whole into account. Neither shareholder nor stakeholder rights (e.g. employees and creditors) can be properly exercised if ultimate decision makers (e.g. controllers) in a company cannot be identified. The accountability of the board may also be seriously endangered if the public is unaware of decision-making and ultimate control structures. Finally, regulators and supervisory agencies have a strong interest to know beneficial owners in order to determine the origin of investment flows, to prevent money laundering and tax evasion and to settle issues of corporate accountability.

However, there is often a lack of clear solutions for (potential) conflicts in listed companies caused by concentrated ownership and control. Concentrated ownership or blockholder

\footnotetext{
${ }^{1}$ This programme is being organised in partnership with the Government of Japan.

${ }^{2}$ See OECD (2009).
} 
structures are a predominant corporate structure and are not illegitimate if proper governance rules are in place. This means that corporate control structures have to operate within a framework of transparency and accountability. It is widely acknowledged that disguised control structures and misuse of corporate vehicles cannot be tolerated.

The accumulation of control in one or more shareholders may very well benefit minority investors by making management more accountable, thereby reducing managerial self-dealing problems. However, controlling shareholders also have incentives to exploit corporate opportunities and engage in abusive related party transactions. The question thus arises whether a country's corporate governance framework is sufficient to protect minority investors and other stakeholders against opportunistic behaviour of controlling beneficial owners.

A good corporate governance framework should combine transparency, accountability and integrity and this requires knowledge of beneficial ownership. The protection of minority investors and other stakeholder protection will be challenging without access to reliable information about the ownership, including the identity of the controlling owners and control structures of listed companies. This report assesses the costs, benefits and practicalities of different approaches, and suggests policy options to better identify ultimate beneficial ownership in Indonesia. Specifically, it:

- Considers a number of policy recommendations and evaluates the impact they may have on a country's corporate governance framework and, more importantly, on a country's business community.

- Assesses the legal and regulatory regimes and practices governing the disclosure and reporting of ownership and control structures in listed companies in various countries around the world. It addresses to what extent and through which channels relevant ownership and control information is reported and provided to the company and its investors, the market, regulators and supervisory authorities.

- Reviews the strategies that are employed to enforce the legal regimes and practices, including mechanisms by which public agents and private economic actors may initiate investigation and enforcement measures to ensure that listed companies and their investors abide by the existing disclosure and reporting rules. 


\section{PART I}

\section{REGULATORY OPTIONS}

\section{General principles}

1. The Indonesian capital market should explicitly embrace the notion of beneficial ownership and control.

2. Definitions of ultimate beneficial ownership should be part of the legal and regulatory framework that governs the disclosure requirements for listed companies.

3. The legal and regulatory framework should ensure that timely and accurate disclosure is made of substantial beneficial ownership interests (and control structures) in listed companies. In order to gradually implement a full disclosure regime, Bapepam-LK may consider providing beneficial owners and listed companies with a one-year transition period to comply with the new disclosure regime.

4. The focus of the legal and regulatory framework should be on enhancing transparency and developing a culture of compliance with the disclosure rules and regulations, which could be achieved by

a) monitoring the implementation of new and revised disclosure rules and regulations on a regular basis,

b) establishing an (informal) advisory committee (involving stakeholders and regional and international experts) to discuss the implementation and future development of disclosure rules and regulations, and

c) requiring Bapepam-LK and other regulatory bodies to share information about regulatory initiatives in the area of disclosure of beneficial ownership and control.

\section{Comment}

Currently, disclosure rules issued by Bapepam-LK, the Capital Market and Financial Institution Supervisory Agency in Indonesia, require the disclosure of direct equity ownership. Bapepam-LK Rule No. X.M.1 states that "only" direct shareholders who own $5 \%$ or more of shares should disclose their holdings, making it very difficult for investors and other stakeholders to identify the ultimate beneficial owner. For instance, under the current disclosure rules and regulations, investors are allowed to hold their shares in an omnibus account maintained by a custodian or sub-custodian. The custodian will appear in the registers of the Central Securities Depository (PT Kustodian Sentral Efek Indonesia - KSEI) as the direct shareholder in a listed company. If an omnibus account holds a substantial number of shares in a listed company, the disclosure is to be made by the respective custodian. In order to improve capital market transparency and bring its disclosure rules and regulations in par with minimum internationally acceptable standards, Bapepam-LK should extend its disclosure regime to also include ultimate beneficial ownership. To this end, a definition of beneficial ownership or beneficial owner that adds precision to the disclosure rules should be introduced. 
The new and revised disclosure rules and regulations can only gain effect if they are accepted and complied with in practice. This could be accomplished by developing a proper and effective enforcement regime, but also by creating a culture of compliance based on transparency, integrity and accountability (in which substantial beneficial owners are actually willing to reveal their controlling positions). In order to increase the practical acceptance of the disclosure regime, Bapepam-LK may consider the introduction of a one-year transition period, which will allow substantial beneficial owners and listed companies to become familiar with the new regime. It should be noted however that in order to comply with the internationally accepted disclosure principles under which substantial beneficial owners fully commit to transparency and accountability towards other investors and market participants (thereby reducing the cost of capital), it is important that beneficial owners and listed companies comply with the new rules and regulations as soon as possible.

Finally, it is strongly recommended that Bapepam-LK align their reform initiatives regarding the disclosure of beneficial ownership and control structures with those of tax regulators and other supervisory authorities. Moreover, Bapepam-LK should consider the establishment of an advisory committee in which regulators, companies, investors, regional and international experts, and other stakeholders are represented. The involvement of international experts will allow for an exchange of information on the effectiveness and future developments of disclosure rules and regulations in an international setting. Furthermore, an advisory committee will help ensure that disclosure rules and regulations are in line with internationally accepted standards that do not discourage substantial (foreign) investments in listed companies in Indonesia.

\section{Disclosure of beneficial ownership and control in listed companies}

5. A tailor-made definition of beneficial ownership/beneficial owner should be included in the disclosure regime in Indonesia. The following general definition of beneficial ownership/beneficial owner could serve as a starting-point: A beneficial owner of a listed company includes any person who, directly or indirectly, through any contract, arrangement, understanding, one or more intermediaries, or otherwise holds - or is able to acquire, on such owner's own initiative, under a formal agreement or other arrangement - securities which provide the owner with (a) the power to vote, or to direct the voting of, one or more outstanding securities of such a company and (b) the power to dispose, or to direct the disposition of, one or more outstanding securities of such a company.

6. Safe harbour provisions that exempt certain parties (such as financial institutions holding shares for the sole purpose of clearing and settlement processes and custodians holding shares in solely their custodian capacity) should be included in the disclosure framework that governs listed companies.

7. Ultimate beneficial owners should be required to disclose direct or indirect holdings of a class of securities in publicly listed companies, based on thresholds starting at $5 \%$.

8. Ultimate beneficial owners who have concluded an agreement to exercise their voting rights in concert with other beneficial owners/shareholders should also be required to disclose their (direct or indirect) holdings, if the accumulated voting rights cross the thresholds defined under (7).

9. Beneficial owners, who have crossed the $5 \%$ threshold, should be required to disclose changes in the ultimate beneficial ownership arrangements (including acting in concert arrangements) to the company, Bapepam-LK and the Indonesian Stock Exchange (IDX) within a reasonable time, not to exceed ten calendar days. 
10. Beneficial owners who are obligated under (7) or (8) to disclose their beneficial ownership and seek to exert control over a publicly listed company should be obliged to disclose in their beneficial ownership statement their intentions, plans, agreements and understandings regarding the listed company, including the intention to acquire additional securities, plan to alter the management, organisation and/or structure of the company (such as mergers, dissolutions, sale of a material amount of assets or any other material reorganisation). Passive investors who do not seek control should be required to disclose direct or indirect holdings of a class of securities in publicly listed companies, but could be exempted from disclosing their intentions.

11. Beneficial ownership should be understood as a material concept. The definition under (5) and disclosure requirements under (7) should be sufficiently open and flexible to allow Bapepam-LK [in collaboration with the Indonesian Stock Exchange (IDX)] to (a) include de facto beneficial ownership structures, (b) take account of technical developments in financial markets, such as cash-settled equity derivatives, and (c) request information beyond the " $5 \%$ ownership" disclosure requirement.

12. Special control structures that deviate from the standard rule that voting rights (control) equals cash-flow rights (ownership), such as pyramid structures and multiple voting shares, should be disclosed annually and prominently in the financial statements and on the websites of listed companies, and updated promptly if there are any changes.

13. Bapepam-LK [in collaboration with the Indonesian Stock Exchange (IDX)] should develop a web-based system that tracks and maintains beneficial ownership and control information collected under the modernised legal and regulatory regimes. Ideally, the information should be publicly accessible and available.

\section{Comment}

Bapepam-LK Rule no. X.M.1 requires all substantial direct shareholders who own 5\% or more of the outstanding shares to send a report containing information about the substantial shareholdings to Bapepam-LK within ten days from the transaction date. Disclosure is mainly made at the level of direct shareholders, providing ample opportunity for ultimate beneficial owners to conceal their identities and controlling interests in listed companies. Moreover, listed companies are required to annually disclose (Bapepam-LK Rule no. X.K.6) and report information in their financial statements (Bapepam-LK Rule No. VIII.G.7) regarding significant direct shareholders who own $5 \%$ or more of the company's shares. This information is made available on the website of the Indonesian Stock Exchange (www.idx.co.id).

However, there is wide consensus in the Indonesian financial market that Bapepam-LK's disclosure rules should be extended to include ultimate beneficial owners. By "simply" including a definition of beneficial ownership/beneficial owners (tailored to the particular circumstances in the economy/business environment in Indonesia), Bapepam-LK's rules could meet minimum internationally accepted standards.

Exemptions can be provided through which certain parties are not deemed to be beneficial owners, but only if there is no public interest in the disclosure of beneficial ownership and control. These exemptions should be stated in a clear and narrowly defined way. Examples are financial institutions holding shares for the sole purpose of clearing and settlement processes and custodians holding shares in solely their custodian capacity. It is, however, understood that these exempted categories remain subject to any special regulatory reporting requirements and disclosure requests by Bapepam-LK.

In order to provide investors with adequate information about the ownership structure of publicly listed companies, it is key that Bapepam-LK also requires substantial beneficial owners to 
disclose the purpose in holding the securities. Only if beneficial owners explicitly certify that the ownership position is not held for the purpose of or with the effect of changing or influencing the control of the listed company, Bapepam-LK may exempt beneficial owners from disclosing their intentions (in which case they only have to disclose their ownership positions).

Finally, it is important to maintain a web-based system that contains the current and relevant information about substantial beneficial owners in companies listed on the Indonesian Stock Exchange (IDX). Examples of well-developed web-based systems are EDGAR (Electronic DataGathering, Analysis, and Retrieval system) in the United States, Bursa LINK in Malaysia or Italy's CONSOB system. The information in these systems is generally publicly accessible and available. Besides Bapepam-LK's web-based system, listed companies must gradually also be obliged to provide the market with relevant information. Particularly, information about controlenhancing mechanisms, such as the issuance of multiple voting rights shares, but also pyramid structures, must preferably be disclosed in the financial statements and on the company's website on an annual basis.

\section{Information about beneficial ownership and control}

14. The Central Securities Depository (PT Kustodian Sentral Efek Indonesia - KSEI), custodians and intermediaries holding shares as nominee or as omnibus account holder should be required to obtain (through special application forms), verify and retain records on beneficial ownership (including the identity of beneficial owners). The records/information should be shared with the relevant regulators [such as Bapepam-LK and Indonesian Stock Exchange (IDX)] on request and only be made publicly available if this is required in the public interest.

15. Tax authorities, financial service providers and other intermediaries involved in the formation and operation of corporate vehicles should be required (through a due diligence regime in line with FATF's 2012 recommendations) to obtain, verify and retain records on the beneficial ownership and control structures (including the identity of beneficial owners) of corporate vehicles.

16. A system, which allows the relevant regulators [Bapepam-LK and the Indonesian Stock Exchange (IDX)] to work together and collaborate with tax authorities and other authorities to collectively initiate and participate in investigations and share information, should be developed to encourage a culture of transparency and compliance.

17. National - unilateral - legal and regulatory provisions to encourage cross-border cooperation and information sharing regarding beneficial ownership and control structures should be implemented.

\section{Comment}

Setting up a chain of corporate vehicles is an effective means to ensure the anonymity of beneficial owners in both listed and non-listed companies (including special purpose vehicles). In fact, the Asia-Pacific Group, a regional body affiliated with the FATF recently recommended that Indonesia should improve its regulatory framework to detect and deter misuse of chains of corporate vehicles that are often employed to conceal a beneficial owner's identity and intentions. The FATF Recommendations (2012), which contain measures that are expected to significantly improve transparency regarding beneficial ownership structures, could act as a starting-point.

The implementation of a regulatory framework to combat corruption and money laundering [based on the FATF Recommendations (2012)] allow financial regulators, such as tax authorities 
and bank supervisors, to obtain access to beneficial ownership information regarding legal entities that are part of a chain of corporate vehicles. The definition of "beneficial ownership" used in the "anti-money laundering" rules and regulations does not necessarily have to be linked to the definition of beneficial ownership, which is implemented to detect substantial owners of listed companies [as discussed in Recommendation (5)]. Nevertheless, it goes without saying that the availability of information about the identity of beneficial owners of a chain of corporate vehicles will arguably provide important insights into ownership and control structures of listed companies.

Here it should again be noted that, besides improving the regulatory system, Indonesian regulators should intensify their domestic and international collaboration efforts. This could be achieved by (i) developing a web-based portal through which governmental agencies could share information (such as ACRA's Bizfile in Singapore) or (ii) setting up a multi-agency task force which aims to protect the integrity of the Indonesian financial market (such as Project Wickenby in Australia). In this respect, it is noteworthy that KSEI recently implemented the requirement to obtain a Single Investor Identity (SID) for each direct investor whose name is registered as an account name in KSEI. Since IDX requires a broker to quote their clients' SID when conducting trades on the IDX, the SID enables investors to not only monitor their shareholdings, but also the respective buy-sell activities through AKSes, an internet-based system for investors to access KSEl's registration system. The AKSes system could well be a first step towards increased collaboration and information sharing among financial regulators in Indonesia. Finally, the implementation of national legal rules - which do not require a bilateral treaty - that encourage information sharing on an international scale should be introduced. These rules encourage mutual recognition and establish mutual reciprocity and collaboration among national supervisory authorities.

\section{Enforcement}

18. A two-layer enforcement system of judicial and non-judicial enforcement mechanisms should be established to encourage beneficial owners to effectively make disclosures.

19. The non-judicial enforcement system does not involve judicial or administrative proceedings. Enforcement could take place through the imposition of "informal" sanctions, including information requests, reprimands and public statements of noncompliance.

20. The judicial enforcement system consists of interventions by regulators (securities regulator, stock exchange, securities commission and/or supervisory authorities) that involve judicial or administrative proceedings and the possible imposition of legal sanctions, including fines, share transfer restrictions and suspension of voting rights.

\section{Comment}

A well-functioning disclosure regime should be supplemented with a mix of non-judicial and judicial mechanisms that encourage beneficial owners to effectively make disclosures and inform the company, other investors and the market about the beneficial ownership and control structure and their intentions. The judicial system with its formal sanctions should complement the informal measures and should be viewed as a last-resort. Indeed, the non-judicial enforcement system could reduce the burden on regulators [such as Bapepam-LK and the Indonesian Stock Exchange (IDX)], is quick and effective, bringing regulators closer to the business community, and encourages cross-border co-operation. 


\section{PART II}

\section{BACKGROUND INFORMATION}

\section{General principles}

\subsection{Why disclosure of beneficial ownership and control?}

The OECD Principles of Corporate Governance state that the governance framework of listed companies should ensure that timely and accurate disclosure is made on all material matters regarding the corporation, including the financial situation, performance, ownership, and governance of the company. This principle is uncontroversial. Without disclosure and transparency, managers and controlling shareholders have ample opportunity to pursue their own interest by taking advantage of the information deficits of other minority investors and stakeholders, such as creditors and employees. Policy makers and regulators tend to tighten the definition of "accurate disclosure" in the midst or aftermath of major corporate governance scandals or economic downturns. ${ }^{3}$ Higher levels of disclosure and transparency are usually expected to deepen capital markets and attract foreign investors. ${ }^{4}$

Disclosure of beneficial ownership and control is viewed as the linchpin of corporate governance. This paper focused on two advantages of a strict disclosure regime. The first is well documented. ${ }^{5}$ Beneficial owners of listed companies, particularly if they have a controlling interest, have an incentive to expropriate minority investors by forcing management to enter, for instance, into related party transactions. The controlling owner may also employ several other strategies to extract resources and assets from firms they control. These include: (i) dilutive share issues, (ii) insider trading, (iii) withholding important information, and (iv) allocation of corporate opportunities and business activities. For a corporate governance system to be effective, it is crucial that minority investors have a means to detect and observe these abusive transactions and other opportunistic activities by controlling owners. The legal and regulatory disclosure regime should thus ensure that investors are provided with a true, accurate and complete picture of ownership and control structures. Moreover, a legal requirement to provide insights into the identity of substantial ultimate beneficial owners discourages them to engage in self-dealing, or otherwise unduly enrich themselves. In addition, a strict disclosure regime also benefits other stakeholders of a listed company as insights into its control and ownership structure arguably prevent excessive risk-taking activities.

\footnotetext{
${ }^{3}$ See Romano (2012).

${ }^{4}$ See, for instance, Skinner (2011) and Whipp (2011).

${ }^{5}$ This report builds on the OECD-Indonesia Policy Dialogue, Disclosure of Beneficial Ownership and Control, Bali, Indonesia, 5 October 2011 and its background paper [see Vermeulen (2013)].
} 
The second advantage is that potential misuse of corporate vehicles can be limited by the maintenance and sharing of information on beneficial ownership and control structures. ${ }^{6}$ In this regard, it is important to note that disclosure of beneficial ownership and control is not only about the protection of minority investors, employees and creditors. There have been increasing concerns about the degree to which corporate vehicles, including corporations, trusts and foundations, are used for tax evasion, money laundering, terrorist financing and other illicit and abusive transactions. Whilst misuse of corporate vehicles is difficult to discover, several international rules and regulations that are concerned with combating corruption and money laundering make it possible to obtain access to beneficial ownership information, often on an international level. This information will not only make corporate vehicles less attractive for parties' criminal activities, but also help increase integrity and transparency in listed companies. Controlling beneficial owners often employ corporate vehicles to conceal their true identity and set up complex ownership structures and arrangements. In fact, abusive and opportunistic behaviour by controlling beneficial owners frequently involves the use of offshore corporate vehicles or international holding structures. ${ }^{7}$

\subsection{Potential costs of disclosure rules and regulations}

The case for strict and rigorous disclosure requirements and regulations seems clear. Yet, a stringent regime could impose considerable costs on firms and society. ${ }^{8}$ These costs can be divided in four related categories. The first category consists of cost consequences of rules and regulations that don't have a clear objective and aren't transparent from a business perspective. ${ }^{9}$ Disclosure rules and requirements that are viewed as unnecessary "red-tape" or are characterised by an inappropriate complexity will significantly undermine compliance, increase disrespect for legal rules and regulation and discourage transparency and accountability in listed companies. The second category of costs stems from the unintended effects of overly strict disclosure regimes to investors. Empirical research seems to suggest that excessive compliance costs, shortening the disclosure period and information overload problems, discourage (foreign) investments in listed companies and negatively affect shareholder engagement. ${ }^{10}$ Legal and regulatory requirements that make investments in listed companies cumbersome and costly also make the initial public offering process less attractive. The third category is costs of a disproportionate and stringent disclosure regime makes it more difficult for emerging growth companies to attract public investors, these companies will be induced to rethink their stock market aspirations, thereby hampering economic growth and job creation. ${ }^{11}$ Finally, the fourth category of costs is related to the inefficient or complete lack of enforcement mechanisms. Similar to the first category of costs, a clear and proportionate enforcement regime is needed to complement the disclosure rules and address potential non-compliance problems. ${ }^{12}$

\footnotetext{
${ }^{6}$ See OECD (2001).

${ }^{7}$ See OECD (2011).

${ }^{8}$ See Bebchuk and Jackson (2011) and Enriques, Gargantini and Novembre (2011).

${ }^{9}$ See, for instance, The Economist (2011b).

${ }^{10}$ See Vermeulen (2013).

${ }^{11}$ See, for instance, Kamar, Karaca-Mandic and Talley (2008).

${ }^{12}$ See Vermeulen (2013).
} 


\subsection{Towards a culture of compliance with beneficial ownership and control disclosure rules in Indonesia}

The trade-off between the costs and benefits of stringent disclosure rules is particularly important to understand the policy options available to Indonesian policy makers and regulators. The Indonesian corporate sector can be characterised as a block holder or concentrated ownership system. Most listed companies are state-owned enterprises. If they are not state-owned, families usually remain in control by holding shares directly or indirectly through, for instance, nominee accounts or pyramid structures. Since these families not only control the decision-making process at the shareholders level, but often also hold management positions throughout the company (Wu Xun, 2005), minority investors have a particular interest in obtaining detailed and adequate information about the ownership and control structures of listed companies. Currently, however, strict rules issued by Bapepam-LK, the Capital Market and Financial Institution Supervisory Agency in Indonesia, only seem to require the disclosure of direct equity ownership, making it very difficult for investors and other stakeholders to identify the ultimate beneficial owner. For instance, Bapepam-LK Rule No. X.M.1 requires all substantial direct shareholders who own $5 \%$ or more shares to disclose their holdings.

The World Bank, in its 2010 Report on the Observance of Standards and Codes (ROSC) regarding the corporate governance country assessment on Indonesia, strongly suggests that Indonesia initiate regulatory reforms aimed at bringing its disclosure rules and regulations in par with internationally acceptable standards. The World Bank recommends several reforms to the legal and regulatory framework. First, definitions of ultimate beneficial ownership should be included in the capital markets laws of Indonesia. Second, Bapepam-LK Rule no. X.M.1 should be extended to also apply to ultimate beneficial owners. Under the revised rule, beneficial owners should disclose their holdings whenever they pass the $5 \%$ level. Third, companies should disclose these positions in their annual report. Fourth and finally, the listed companies should disclose the control-enhancing mechanisms, such as special voting rights and crossshareholdings in their financial statements and on their websites.

One way to initiate the reforms is by transplanting tried-and-tested disclosure systems from other countries. The process of transplanting disclosure rules is often taken one step further by studying the possibility of implementing additional corporate governance mechanisms or approaches that have been successfully introduced in other legal systems. An example of a possible transplant is Brazil's Novo Mercado, a new listing segment in Brazil for companies that want to signal their compliance with strict corporate governance and disclosure practices. ${ }^{13}$ In the context of corporate governance and disclosure, the examination of international rules and institutions usually helps policy makers and regulators discover new insights that could lead to improved rules, standards and best practices. ${ }^{14}$ Still, there are problems with pushing the transplanting process too far. The results of comparative studies often lack a clear theoretical or empirical explanation of why a particular system or institution is the most suitable model for a country, given its specific cultural, social, economic and business characteristics. Countries that rely too much on the success of the transplanting process run the risk of introducing unclear rules and regulations that are not only mis-interpreted by local market players, but also too costly or

\footnotetext{
${ }^{13}$ See World Bank (2006).

${ }^{14}$ See, for instance, Katz and McIntosh (2012), attempting to convince the US Securities Regulator [the Securities and Exchange Commission (SEC)] to modernise the disclosure rules and regulations by referring to the disclosure rules in the United Kingdom, Germany, Canada and Hong Kong, China.
} 
impossible to implement in practice due to the lack of sufficient supervision or enforcement systems. $^{15}$

Rather than just providing a number of possible reform strategies that could be used and implemented by Indonesian capital market regulators, this report argues that reform measures undertaken by national level governments are best seen in terms of a spectrum of possible reform paths. It ranges from countries with strict corporate governance mechanisms via countries that focus foremost on the implementation of stringent transparency regimes to jurisdictions that offer proportionality and flexibility in their disclosure rules and regulations. Illustrations of recent corporate governance and disclosure reforms demonstrate how the trajectory of regulatory trends tends to map on the spectrum of legal reform. More importantly, the regulatory spectrum approach provides an effective analytical framework that assists policy makers and regulators in Indonesia in designing disclosure rules and regulations that will be accepted and complied with in practice.

This report shows that it is not only about introducing strict rules and regulations, but also about creating a compliance culture in which beneficial owners feel comfortable in revealing themselves. This can be achieved if policy makers, regulators and private parties work together to implement and enforce disclosure rules and regulations that will eventually lead to more robust capital markets in which transparency is understood to reduce uncertainty and the cost of capital, making it more attractive for firms to carry out initial public offerings (IPOs) in Indonesia and for investors to put their money in Indonesian companies.

\subsection{Structure of the report}

This report provides legislative and regulatory options for policy makers and regulators in Indonesia seeking to reform the disclosure of beneficial ownership and control regimes. It mainly proposes options that will improve the corporate governance framework for listed companies. An important focus of the first section of the report will be on questions regarding the definition of beneficial ownership and, more importantly, disclosure of beneficial ownership and control. In this regard, the first question that arises is whether the definition of disclosure of beneficial ownership should be all encompassing, formal and strict or whether it should provide for some flexibility to better capture new alternative investment techniques, such as cash-settled equity derivatives. Arguably, a sufficiently flexible definition is needed to not only allow for a proportionate application of the disclosure regime, but also to limit the unintended and negative effects of strict and mandatory rules and requirements. The question that immediately follows, however, is how to deal with proportionality. These and many more questions will be addressed: Who should disclose changes in beneficial ownership and control structures? When should these changes be disclosed and to whom? What information should be disclosed? Through which channels should beneficial ownership and control be reported? Who will have access to the reported information?

The second and third sections discuss mechanisms that encourage compliance with the disclosure rules and regulations. The focus will be particularly on information gathering and enforcement. The report comments on the role of custodians and intermediaries, the information sharing between governmental and non-governmental agencies and judicial and non-judicial enforcement approaches. It should be noted, however, that the report focuses on key issues and does not attempt to set out a detailed blueprint for a disclosure regime. The report contains nonbinding recommendations that build on the OECD background paper Beneficial Ownership and Control: A Comparative Study - Disclosure, Information and Enforcement (Vermeulen, 2013) and the

\footnotetext{
${ }^{15}$ See Pistor and Xu (2003).
} 
OECD-Indonesia Policy Dialogues on Disclosure of Beneficial Ownership and Control which took place in Bali on 5 October 2011 and Jakarta on 16 February 2012.

\section{Disclosure of beneficial ownership and control in listed companies}

\subsection{Initial public offerings and listed companies: Regulation or deregulation?}

Listed companies are important to a country's economy. ${ }^{16}$ Certainly, small and medium-sized non-listed enterprises are usually viewed as the backbone of the economy. ${ }^{17}$ However, recent empirical research shows that larger listed companies are key to economic growth and development. ${ }^{18}$ For instance, approximately $90 \%$ of job growth for venture capital backed companies occurs after the initial public offering (IPO). A recurring emphasis on capital market design becomes apparent. Healthy capital markets are central to innovation and economic development; ${ }^{19}$ they supply firms with cost-effective access to funding by linking companies to public equity; they are pivotal to the inception of venture capital (VC) markets, since IPOs constitute exit mechanisms in which VC funds obtain significant returns on their investment and founding entrepreneurs regain control of their newly listed company; ${ }^{20}$ they make diversified investment portfolios available, thereby making the spreading of risks possible. It can hardly be contested that fostering and deepening capital markets must be at the top of the policy agenda for both developed and developing countries. This is particularly true as high potential growth companies increasingly exhibit a significant home bias when considering an IPO. ${ }^{21}$

Thus, the issue at hand is the search for the optimal legal and regulatory regime that not only allows for the development of deep and liquid capital markets (by protecting minority investors), but also encourages IPOs by smaller, emerging growth companies. Here, two approaches come to mind. First, while Box 1 (which shows the number of listings on and de-listings from NASDAQ) seems to indicate otherwise, ${ }^{22}$ it may nevertheless be preferable to increase the stringency of corporate governance standards for listed companies, including disclosure rules and regulations, as a means to promote investor confidence. Another way of going about it involves a more flexible approach to securities regulation. The latter system usually builds on the reputation and quality of supervisory authorities, advisors and other gatekeepers that operate in the market. ${ }^{23}$

\footnotetext{
${ }^{16}$ See Kenny (2011) and The Economist (2011c).

17 See OECD (2000).

${ }^{18}$ See The US Department of the Treasury (2011).

${ }^{19}$ See Mendoza and Vermeulen (2011).

${ }^{20}$ See Black and Gilson (1998).

${ }^{21}$ Empirical research shows that $91 \%$ of the 162 VC-backed companies that pursued an IPO in the period 1 January 2011 to 30 November 2011 exhibited a "home-bias" by listing at a domestic stock exchange. See Vermeulen (2011).

22 See The US Department of the Treasury (2011).

${ }^{23}$ An example of a stock market that embraces flexible rules is the Alternative Investment Market (AIM), a sub-market of the London Stock Exchange, designed to satisfy smaller companies that want to float their shares. AIM companies benefit from flexible rules that set low hurdles IPOs and few ongoing obligations for listed companies as compared to other stock exchanges. AIM's investor base is largely made up by sophisticated institutional investors, which maintain close ties with the companies they invest in. What is more important is that the exchange has partially delegated its regulatory authority to the so-called Nominated Advisers (Nomads): private firms that supervise and provide counsel to AIM firms. Nomads play multiple roles as gatekeepers, advisers and regulators of AIM. Nomad performance is driven by a unique incentive structure in which their reputational capital is pledged as a proxy for the suitability of firms admitted to AIM, the accuracy of ongoing disclosure and the quality of internal governance structures. See Mendoza (2007).
} 
On one end of the spectrum, there is Brazil's Novo Mercado, a listing segment with high and stringent standards of corporate governance and disclosure. Companies usually opt-into this voluntary premium segment to show credibility and trustworthiness.

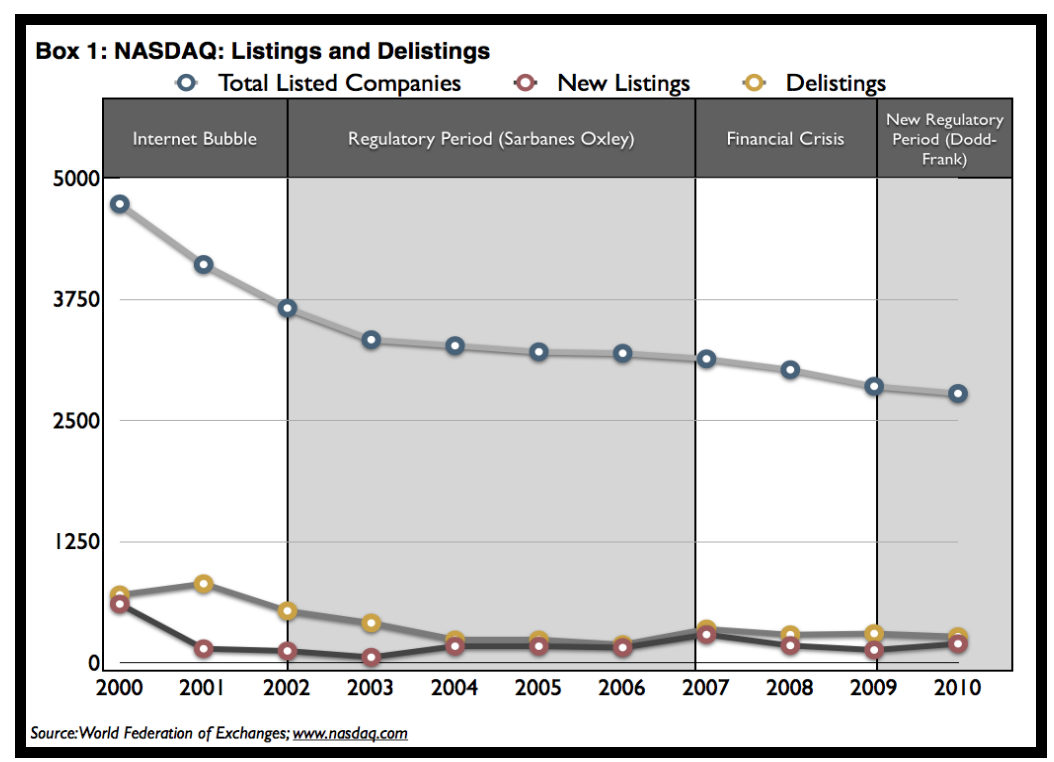

On the other end of the spectrum is the United States. ${ }^{24}$ The regulatory regime gives the Securities and Exchange Commission (SEC) the authority, flexibility and guidance to conduct their responsibilities effectively in an ever-changing technological and economic environment. Malaysia could long be found on the "rules-based" end of the spectrum. After the Asian financial crisis in 1997, a strict regulatory approach was considered appropriate to enhance transparency and restore confidence in the financial market. In 2005, a move towards the more flexible "principle-based" side of the spectrum was felt necessary to become a more attractive environment for both domestic and foreign companies and investors. Below is a discussion of the spectrum, starting with Brazil.

\subsection{Brazil's Novo Mercado: Stringent corporate governance and disclosure rules}

Countries with a less developed capital market must typically rely on the promulgation of more stringent listing rules and disclosure regulations in their efforts to improve investor protection, encourage listings and attract foreign investors. For instance, Brazil's Novo Mercado, BM\&FBOVESPA's highest listing segment, which has been celebrated as a pathway to more liquid equity markets in other emerging economies. A recent study into Novo Mercado shows that designing special listing segments with higher corporate governance and disclosure standards is indeed a pivotal step in widening and deepening domestic capital markets. ${ }^{25}$ Records show that over 100 companies are currently listed on Novo Mercado, making BM\&FBOVESPA the 27th stock exchange in the world following the Indonesian stock exchange. ${ }^{26}$ Particularly, foreign investors are attracted by the venue's strict rules, making it unnecessary for Brazilian companies

\footnotetext{
${ }^{24}$ Implementation of the Dodd-Frank act, which was passed in the aftermath of America's financial crisis, would arguably lead to an extraordinarily complex regulatory environment. In this respect, the Dodd-Frank act is a perfect example to show that the costs of regulation could very well outweigh the benefits. See The Economist (2012).

${ }^{25}$ See Gorga (2009).

${ }^{26}$ See Di Miceli da Silveira (2010).
} 
to pursue a costly and time-consuming dual listing. Interestingly, even high potential - venture capital backed - firms, although still relatively small in number in Brazil, are willing to bear additional compliance costs in exchange for access to a robust capital market (Gorga and Mascarenhas, 2010). It is therefore not surprising that, in order to overcome investor anxiety and distrust, Brazilian listed firms increasingly adhere to Novo Mercado's stricter corporate governance and disclosure practices (see Box 2).

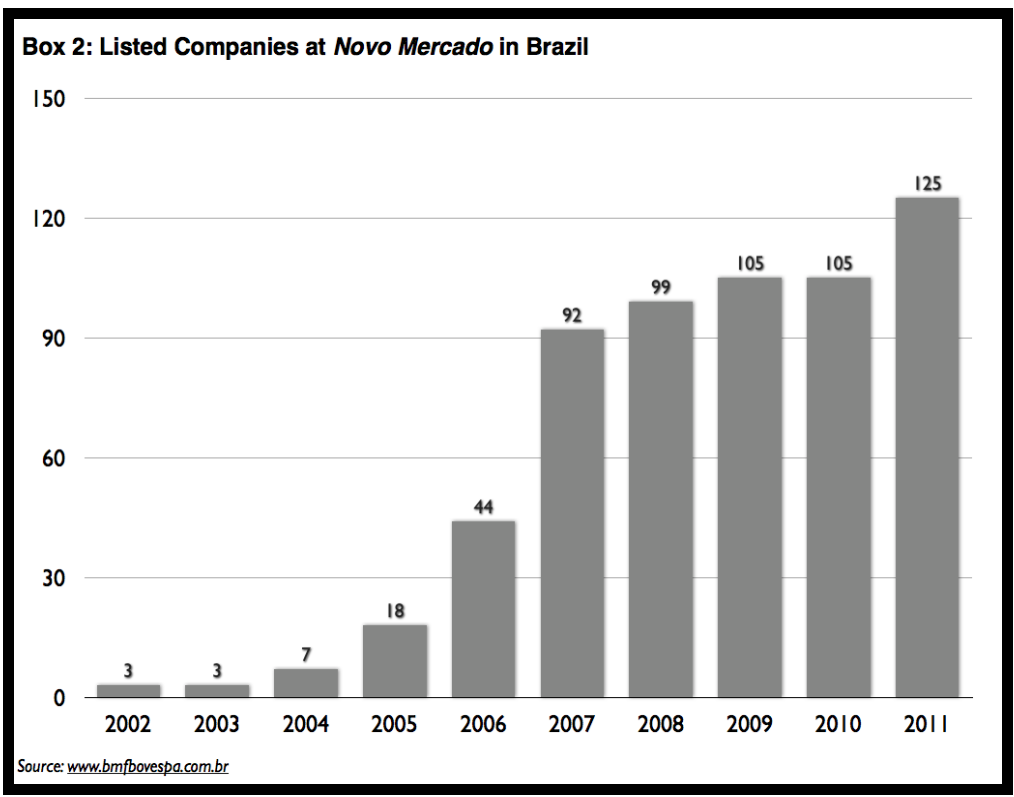

Besides the introduction of Novo Mercado, Brazilian lawmakers and regulators have also implemented stricter disclosure requirements. Instruction No. 358 of 3 January 2002 and Circular Note CVM/SEP 01/2010 of the Securities Commission of Brazil (Comissão de Valores Mobiliários or CVM) impose on both domestic and foreign investors in listed companies (irrespective of the listing segment) the obligation to notify CVM if shareholdings reach, exceed or fall below $5 \%$ (or a multiple of $5 \%$ ) of a class of outstanding shares. ${ }^{27}$ What is more important is that CVM Instruction No. 480 of 7 December 2009 requires the listed company to disclose information relating to the beneficial owner of more than $5 \%$ of certain equity securities within seven days after the $5 \%$-threshold is crossed. The relevant information should be disclosed by filing an updated electronic Reference Form with CVM. Finally, it should be noted that Brazil is a beneficial ownership market. It does not recognise nominee ownership. Trades in shares of listed companies are registered in the name of the final beneficial owner with the Stock Exchange, the Central Depository and the custodian. ${ }^{28}$

The experience in Brazil is viewed as evidence that enhanced regulation for beneficial ownership disclosure may not only add to the attractiveness and robustness of a capital market in developing economies, but that it may also help avoid systemic risk issues. Investors unconcerned with the threat of expropriation by ultimate owners are arguably more inclined to invest into listed companies without discounting the price paid for the shares. Perhaps the most important reason for the success and growth of the Novo Mercado is its design as a new listing segment on top of the old regime. This regulatory approach, which is referred to in the literature as Regulatory Dualism, has the advantage that proponents of the established regime (and

\footnotetext{
${ }^{27}$ See Deutsche Börse Group (2011b).

${ }^{28}$ See BEST (n.d.) and Deutsche Börse Group (2011a).
} 
opponents of the new regime) have fewer incentives to oppose the newly designed rules and regulations. ${ }^{29}$

However, despite the decrease in the cost of capital and other economic accomplishments witnessed in Brazil after the introduction of Novo Mercado, the implementation of a stricter legislative and regulatory regime appears to have its shortcomings. As mentioned earlier, imposing higher standards increases listing costs to a point at which IPOs may become unaffordable for smaller high growth companies. Also, if compliance costs exceed investors' benefits, stricter regulation may not generate the coveted effect. For instance, as will be discussed in more detail below, Brazilian companies on Novo Mercado appear to comply with the stricter rules and requirements (theoretical compliance), but empirical research shows that they often find ways to introduce deviations from these rules in practice (giving investors and other market participants a wrong impression about the control structure of the company). ${ }^{30}$ The challenge of closing the gap between theory and practice can be dealt with by introducing even stricter rules and regulations that prohibit these deviations. However, this may make the regime less responsive to social and economic changes as well as needs of companies and investors in the future. ${ }^{31}$

Despite these shortcomings, several other countries, such as Turkey, India and the Philippines, have been inspired by the Novo Mercado initiative. It has even been argued that Bapepam-LK should investigate the possibility of devising an additional listing segment characterised by stricter corporate governance and disclosure rules. ${ }^{32}$ Here it is important to emphasise that Brazil's particular social and economic situation at the time of the launch of the Novo Mercado at the end of 2000 - which may differ significantly from the current social and economic situation in other developing economies - generates at least some uncertainty as to the possibility of successfully transplanting Brazil's strict regulatory approach in other markets, such as Indonesia. ${ }^{33}$

What are the circumstances that made Novo Mercado an attractive venue for listings? When the new listing segment was launched, it was considered to become a market for IPOs. The preNovo Mercado companies were characterised by controlling shareholders who had a minority of the cash-flow rights, but a majority of the voting rights through the issuance of dual class stock. Non-controlling shareholders usually owned non-voting preferred shares. Since Novo Mercado prohibited the issuance of these preferred shares, it was not expected to be attractive to existing companies. However, the predictions proved wrong. The Argentine crisis, the 9-11 attacks on the World Trade Center, and the devaluation of Brazil's currency practically dried up the IPO market (Novo Mercado only became the choice of venue for IPOs as of 2004). During the first years of its existence, Novo Mercado seemed doomed to failure when the unexpected occurred. A network of collaborations and partnerships between governmental and private parties spontaneously emerged and encouraged existing listed companies to convert their ownership structure and consider a listing at Novo Mercado. The framework in which regulators, securities commissions, institutional investors, corporate governance institutions and international

\footnotetext{
${ }^{29}$ See Gilson, Hansmann and Pargendler (2010).

${ }^{30}$ See Santana, Ararat, Alexandru, Yurtoglu and Rodigues da Cunha (2008).

${ }^{31}$ See Santana (2012).

32 See, for instance, The World Bank (2006).

${ }^{33}$ See Licht (2000).
} 
organisations work together, arguably played a pivotal role in the success of Novo Mercado in its first years of existence. ${ }^{34}$

It follows from the discussion above that one of the most distinguishing features of BM\&FBOVESPA's Novo Mercado is the mandatory enforcement of the one-share-one-vote rule. Under this rule, the shares of a listed company must grant its holders an equal amount of voting and cash flow rights. Novo Mercado's one-share-one-vote rule is enforced through limitations on the issuance of different classes of shares, multiple voting shares and non-voting preferred stock. The ultimate purpose of the one-share-one-vote rule is (i) to reduce the incentives of controlling parties to expropriate minority investors and (ii) to stimulate the emergence of a "market for corporate control" in which the threat of hostile takeovers motivates managers to take the interests of shareholders into account. ${ }^{35}$ Moreover, as discussed, the practical impact of Novo Mercado's one-share-one-vote rule should not be overstated. ${ }^{36}$ Shareholders agreements and strict takeover defences in most companies' bylaws allow shareholder groups to retain significant control over their Novo Mercado companies without holding the majority of the outstanding shares. ${ }^{37}$

Instead of prohibiting deviations from the one-share-one-vote rule, policy makers and regulators could consider the implementation of enhanced disclosure requirements for such deviations. There are two reasons for this. In order to make a well-considered investment decision, investors should be informed about specific control structures and arrangements in listed companies. It is necessary that disclosure rules and regulations require companies to report the use of controlenhancing mechanisms such as multiple voting shares in their prospectuses, financial statements and on their websites. Secondly, tightening the disclosure regime will not only lead to more transparency, but will also decrease the use (and popularity) of these mechanisms. ${ }^{38}$ That is not to say that investors are not able to distinguish between companies that legitimately and proportionally implement control mechanisms and companies with disproportional structures. For instance, the use of dual class shares is not uncommon in listed family firms and high-tech (fastgrowing) companies. ${ }^{39}$ Control-enhancing mechanisms may even be considered best practice or viewed as a competitive advantage during a growth or restructuring phase. Due to the fact that dual class structures expose the controlling shareholders (who are often the family or founders behind the company) to the business world, it gives them an incentive to pursue long-term goals and monitor the firm's management closely, often resulting in outstanding performances. High tech companies, such as Google and Linkedln, are companies with a "supervoting stock" structure, but also companies in more traditional sectors, such as French luxury giant LVMH, employ dual class voting shares, providing families with the majority of the voting rights, while having a minority of the cash flow rights. ${ }^{40}$ Below is a discussion of a country with a strong focus on transparency and disclosure: Malaysia.

\footnotetext{
${ }^{34}$ See Santana, Ararat, Alexandru, Yurtoglu and Rodigues da Cunha (2008).

${ }^{35}$ See McCahery and Vermeulen (2011).

${ }^{36}$ See Gilson, Hansmann and Pargendler (2010).

37 Enhanced mandatory bid provisions, ranging from $10-35 \%$ of the company's shares, together with predefined minimum premium requirements ensure that no other shareholders can build a significant stake in the respective company. See Gilson, Hansmann and Pargendler (2010).

${ }^{38}$ See Vermeulen (2013).

${ }^{39}$ See Mendoza, Van der Elst and Vermeulen (2010).

${ }^{40}$ See Smith (2011).
} 


\subsection{Malaysia's reforms: From stringent towards proportionate disclosure rules}

Before the 1997 Asian financial crisis, Malaysia only had basic requirements on beneficial ownership (see Box 3). Notification requirements were largely avoided by using (and abusing) nominee accounts. Consequently, regulators and investors had no reliable information about companies' beneficial ownership and control structures. The government reacted to the crisis by introducing detailed and strict rules to restore investors' confidence in the financial market. The 1997 reform focused on enhancing transparency regarding beneficial ownership and control. In order to prevent financial crises in the future, the use of "unauthorised" nominee accounts was prohibited. It became mandatory to dematerialise the shares that were floated on stock exchanges and to hold them in book entry form.

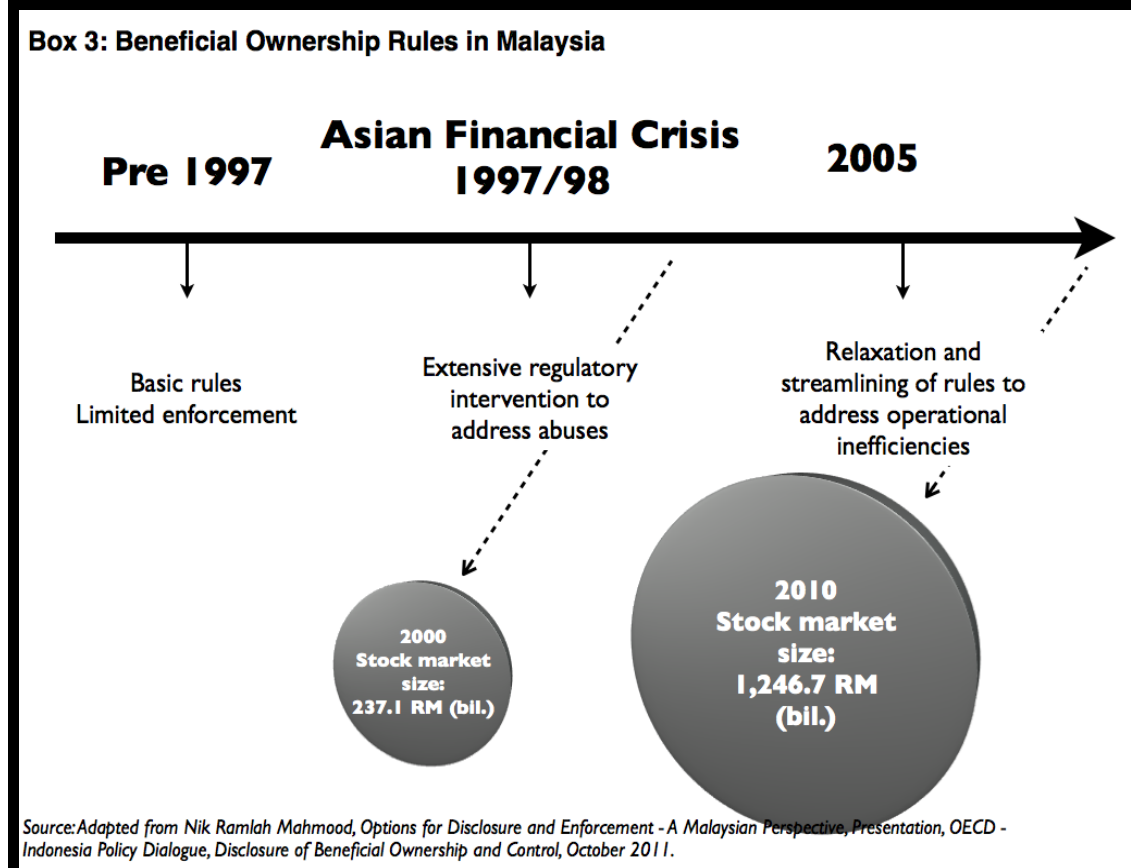

The reform also amended the definition of a substantial shareholding in listed companies. Under the 1997 reforms, a shareholding was substantial and had to be disclosed if a shareholder held $2 \%$ (instead of $5 \%$ ) of a class of equity. More importantly, under the new regime, the focus shifted from the direct shareholder to the ultimate beneficial owner of the shares. Securities accounts with the central depository (i.e., Bursa Malaysia Depository Sdn Bhd) had to be opened in the name of the beneficial owner of the deposited securities or in the name of an authorised nominee (being a person who is authorised to act as a nominee as specified under the Depository Rules).

There is little doubt that the more stringent and detailed disclosure regime has increased investor confidence in the Malaysian capital market. However, the strict beneficial ownership approach also acted as a hindrance to invest in Malaysia. The excessive compliance costs attached to the 1997 reforms eventually spurred the government to relax and streamline the regime in 2005 (see also Box 3 ). This was reflected in, for instance, the increase of the substantial shareholding threshold back up to $5 \% .{ }^{41}$ The shareholder who owns - alone or in concert with other

\footnotetext{
${ }^{41}$ It is fair to say that the regulatory $5 \%$ threshold to disclose beneficial ownership is the international norm. Countries that implemented a stricter threshold, like Malaysia and Italy, have taken or are taking measures to relax the rules. In Italy, for instance, there is evidence that institutional investors keep their participations just below
} 
shareholders - a substantial stake in a company has a duty to ensure that a notice is sent to the company within seven days after becoming a substantial shareholder. ${ }^{42}$ Furthermore, the regulator expanded the list of authorised nominees. Perhaps the most important change was that an implicit "principle of proportionality" was embedded in the 2005 regime. To ensure that the rules would be applied proportionally, the new disclosure regime offers "opt-in rules" for companies and supervisory authorities. Malaysian listed companies, for example, may request its shareholders to unveil beneficial ownership information beyond the $5 \%$ threshold requirement. Likewise, the Registrar of Companies at the Companies Commission may submit a similar request. Another example can be found in the Capital Markets \& Services Act 2007 (CMSA). Section 317(1) imposes on directors of listed companies a duty to inform the company about any of the shares owned. The Securities Commission may request this information if it deems necessary. Moreover, the authorised nominees could be asked to provide information about the underlying securities. The combination of certainty and flexibility in the regulatory framework played a pivotal role in "strengthening the profile of Malaysia as an attractive investment and fundraising destination". ${ }^{43}$ The balanced regulatory framework is one of the factors (not at all the only factor) that contributed to the growth of the Malaysian stock market (see again Box 3), making it the $15^{\text {th }}$ stock exchange based on the number of listed companies.

\subsection{The United States: Proportionality and flexibility in disclosure of beneficial ownership}

It can be argued that the United States is a "beneficial ownership market" that offers a proportionate regime for the disclosure and reporting of ownership and control structures in listed companies. Sections 13(d) and 13(g) of the Securities and Exchange Act of 1934 (Exchange Act) require a person who is the beneficial owner of more than $5 \%$ of certain equity securities to disclose information relating to such beneficial ownership within 10 calendar days after the Section 13(d) threshold is crossed. Disclosures under Sections 13(d) and 13(g) must be filed electronically through the SEC's Electronic Data Gathering, Analysis, and Retrieval system (EDGAR). The filings are immediately publicly available through EDGAR's portal. Also, Section 13(d) states that beneficial owners who seek control must disclose their ultimate intentions (see Box 4). Passive investors without any intention to control the company are allowed to file a shortform document. While these statutory sections do not define the term "beneficial owner", the Commission has adopted Exchange Act Rule 13d-3, which sets forth a broad "principle-based" definition of beneficial ownership and control. Generally, beneficial owners are defined under Rule 13d-3(a) as persons who may, directly or indirectly, vote or dispose or direct the voting and disposition of a voting class of equity securities. The flexibility in the US disclosure and reporting regime has allowed it to adapt and evolve with market developments.

On 7 March 2011, however, the Commission received a petition for rulemaking submitted by a law firm recommending amendments to the regulatory system. ${ }^{44}$ The petition specifically requested that the period within which beneficial ownership reports must be filed with the Commission be shortened. The petition also asked the Commission to broaden the definition of beneficial ownership to explicitly include derivative instruments. Subsequent to this petition for

the $2 \%$ threshold. They are reluctant to disclose their positions, which will undoubtedly lead to an increase in compliance costs. CONSOB, the Italian securities regulator, decided to raise the threshold for mutual funds. Still, this measure is probably not enough. The pressure to change the rules for all investors is increasing in Italy.

${ }^{42}$ See Vermeulen (2013).

${ }^{43}$ See Securities Commission Malaysia (2010).

${ }^{44}$ See Vermeulen (2013). 
more stringent rulemaking, another law firm acting on behalf of institutional investors submitted a paper to the SEC opposing the change on the ground that shortening the time period would be bad for all investors. Other parties have also submitted comments disagreeing with the views expressed in the original petition. The SEC has not proposed any rule changes so far, and it is currently not clear if and whether the SEC will do so. In the summer of 2011, the SEC also declined to propose any changes to the relevant rules so as to treat cash-settled equity derivatives as conferring beneficial ownership. ${ }^{45}$

\section{Box 4: Schedule 13D Under the Securities Exchange Act of 1934}

\section{Item 4. Purpose of Transaction (Intention)}

(i) State the purpose or purposes of the acquisition of securities of the issuer. Describe any plans or proposals which the reporting persons may have which relate to or would result in:

(ii) The acquisition by any person of additional securities of the issuer, or the disposition of securities of the issuer;

(iii) An extraordinary corporate transaction, such as a merger, reorganization or liquidation, involving the issuer or any of its subsidiaries;

(iv) A sale or transfer of a material amount of assets of the issuer or any of its subsidiaries;

(v) Any change in the present board of directors or management of the issuer, including any plans or proposals to change the number or term of directors or to fill any existing vacancies on the board;

(vi) Any material change in the present capitalization or dividend policy of the issuer; Any other material change in the issuer's business or corporate structure, including but not limited to, if the issuer is a registered closed-end investment company, any plans or proposals to make any changes in its investment policy for which a vote is required by Section 13 of the Investment Company Act of 1940;

(vii) Changes in the issuer's charter, bylaws or instruments corresponding thereto or other actions which may impede the acquisition of control of the issuer by any person;

(viii) Causing a class of securities of the issuer to be delisted from a national securities exchange or to cease to be authorized to be quoted in an inter-dealer quotation system of a registered national securities association;

(ix) A class of equity securities of the issuer becoming eligible for termination of registration pursuant to Section 12(g)(4) of the Act; or

(x) Any action similar to any of those enumerated above.

There is something to the call for stricter disclosure and reporting rules and regulations. Minority investors benefit in some ways if they are instantly provided with the true picture of ownership and control structures and, more importantly, the identity of the persons who should be considered as the ultimate beneficial owner. However, as the Malaysian experience indicates, compliance costs may outweigh potential benefits when rules and regulations are tightened. For instance, stricter rules, particularly rules that shorten the disclosure period, could seriously decrease shareholders engagement in the monitoring of a company and its management. Indeed, shareholders' monitoring and disciplining activities can often be explained by a listed company's stock price not reflecting a company's growth potential. Too strict and disproportional disclosure rules that oblige shareholders to disclose their significant positions at a very early stage without being able to benefit more from relatively low stock prices discourage shareholders from engaging in monitoring activities, which may hurt minority investors. ${ }^{46}$ Moreover, an inflexible and strict regime without exemptions arguably leads to irrelevant information being

\footnotetext{
${ }^{45}$ See Vermeulen (2013).

${ }^{46}$ See Bebchuk and Jackson (2011).
} 
provided. ${ }^{47}$ Arguably, the costs of information overload will be reduced if disclosure regulations only target beneficial owners who seek control over a company. ${ }^{48}$

\section{$2.5 \quad$ Indonesia: The next steps}

So far three legislative and regulatory approaches were highlighted that appear on the spectrum for beneficial ownership and control rules and regulations. Even though all regimes can be characterised as "beneficial ownership" markets (where disclosure goes beyond the level of direct shareholders), there are some distinctions. The first position is characterised by a strict rules-based approach that companies can opt-in to. An example of a jurisdiction that takes this position is Brazil. Malaysia is placed near the midpoint of the spectrum. The Malaysian disclosure regime contains a strict set of minimum disclosure requirements. Supervisory authorities (the Corporate Regulator, the Stock Exchange, the Central Depository and the Securities Commission) have some flexibility in the application of the rules. For instance, they are entitled to extend the application by requesting more information if deemed necessary. The United States occupies a "principle-based" position regarding the regulation and disclosure of beneficial ownership. For example, the Exchange Act contains disclosure exemptions for investors who have no intention to exert control over the listed company.

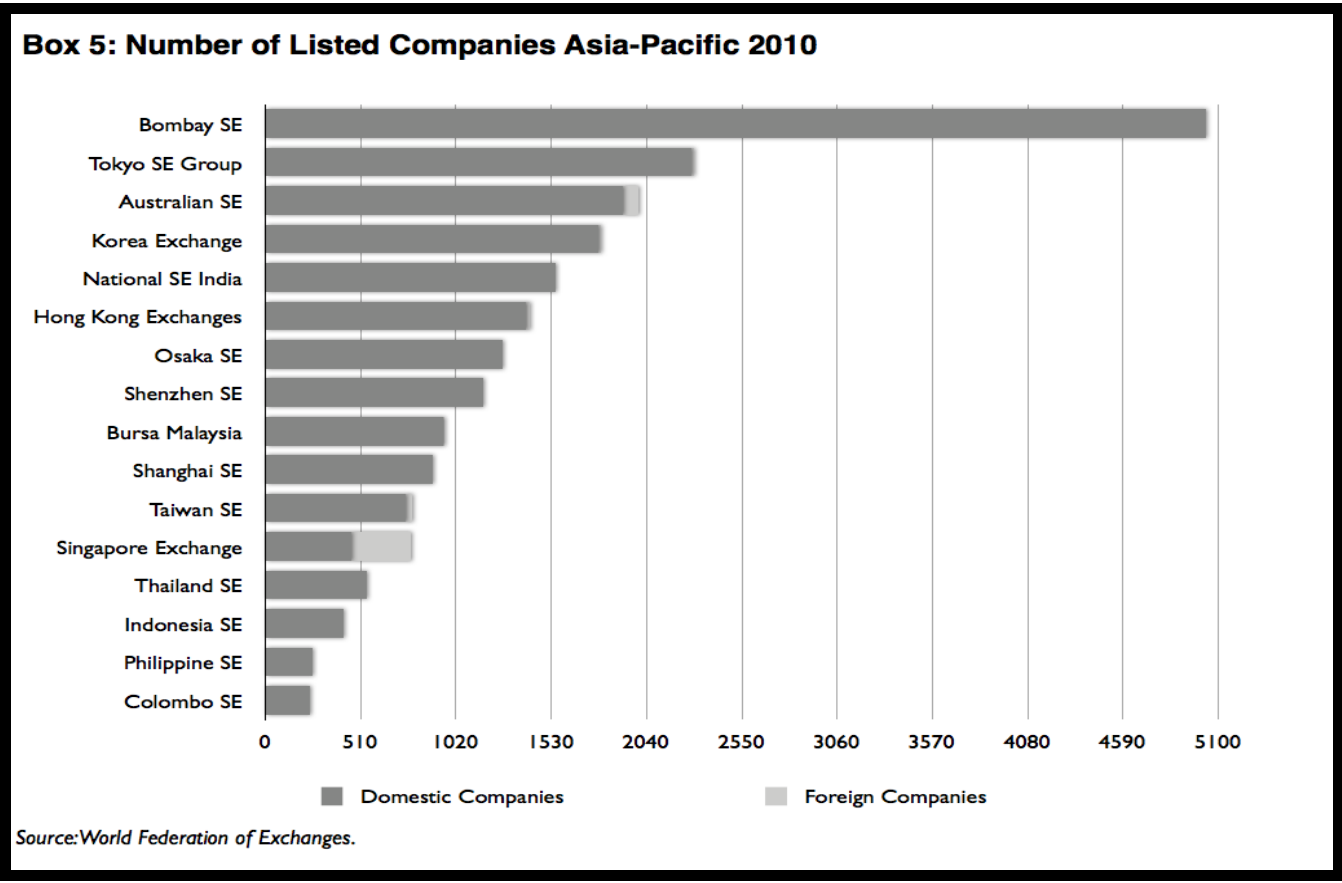

What could be Indonesia's position on the regulatory spectrum? The Indonesian Stock Exchange ranks $14^{\text {th }}$ in number of listed companies in the Asia-Pacific region (see Box 5). ${ }^{49}$ The Bombay

\footnotetext{
47 See for instance European Commission, Proposal for a Directive of the European Parliament and of the Council amending Directive 2004/109/EC on the harmonisation of transparency requirements in relation to information about issuers whose securities are admitted trading on a regulated market and Commission Directive 2007/12/EC, COM (2011) 683 final, 25 October 2011. The proposal seeks to address the "hidden ownership" and "empty voting" issues by extending the disclosure requirements to cash-settled equity derivatives. The European Securities and Markets Authority (ESMA) is entrusted with ensuring a consistent and proportionate application of the Directive by drafting regulatory technical standards and updating an indicative list of financial instruments that should be subject to disclosure.
}

${ }^{48}$ See European Commission (2011). 
stock exchange has the most listed companies followed by the Tokyo Stock Exchange. Singapore attracts most foreign companies. If transparency in the ownership and control structures of listed companies is one of the most important determinants of the attractiveness of a stock exchange, Indonesia could make a giant leap forward in becoming a more attractive capital market by extending the disclosure requirements to beneficial owners. As noted above, the current regulatory regime in Indonesia mainly requires the disclosure and reporting of direct shareholdings (see also Box 6). Listed companies are required to annually disclose (BapepamLK Rule No. X.K.6) and report information in their financial statements (Bapepam-LK Rule no. VIII.G.7) regarding significant direct shareholders who own $5 \%$ or more of the company's shares. This information is made available on the website of the Indonesia Stock Exchange (www.idx.co.id).

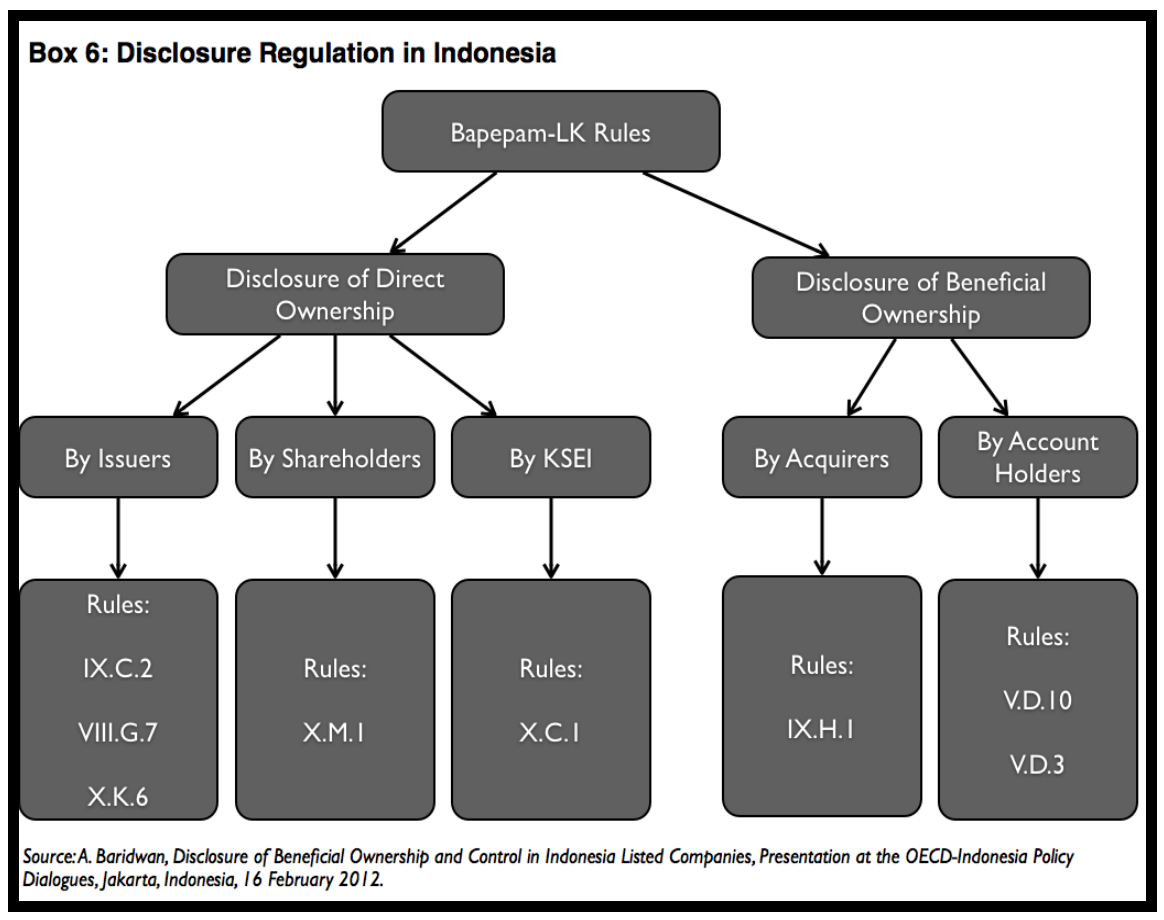

In addition, Bapepam-LK Rule no. X.M.1 requires all substantial direct shareholders who own 5\% or more of the outstanding shares to send a report containing information about the substantial shareholdings to Bapepam-LK within ten days from the transaction date. The report includes the following information: (i) the name, address, and nationality of the shareholder, (ii) the number of shares purchased or sold, (iii) the purchase and the selling price, (iv) the date of the transaction, and (v) the purpose of the transaction. Finally, the Central Securities Depository (PT Kustodian Sentral Efek Indonesia - KSEI) is required to periodically submit activity reports to Bapepam-LK regarding changes in substantial shareholdings (which is defined as $5 \%$ or more) in listed companies (Bapepam-LK Rule no. X.C.1). The Indonesia Stock Exchange (Bursa Efek Indonesia - IDX) must publish the reports in its reporting system.

Thus, companies listed on IDX are subject to a strict and comprehensive disclosure regime in which both governmental agencies and self-regulatory organisations, such as KSEI, are involved. However, the scope of the disclosure regime is arguably too narrow. Disclosure is mainly made at the level of direct shareholders, providing ample opportunities for ultimate beneficial owners to

\footnotetext{
${ }^{49}$ See www.world-exchanges.org.
} 
conceal their identity and controlling interest in listed companies. There are, however, strong signals that Indonesia is on the brink of ushering in a "new" disclosure system that focuses on beneficial ownership and control structures. First, it is presumed that a broad interpretation of Article 87 of the Capital Market Law 1995 includes the disclosure obligation for substantial beneficial owners. Article 87 requires directors and members of the supervisory board to disclose their shareholdings and changes in their shareholdings. Article 87 also applies to other persons or legal entities that hold directly or indirectly $5 \%$ of a listed company's equity stock. In this respect, Article 87 goes beyond direct shareholdings, including also the disclosure of ultimate share ownership. Second, Bapepam-LK Rule no. IX.H.1 states that in the event of an acquisition of a listed company, the acquirer must immediately (one day after the acquisition) disclose, among other things, its ownership structure as well as the identity of the beneficial owner. Third, the "know your client" principle, as stated in Bapepam-LK Rule No. V.D.10, requires financial service providers to obtain information about the clients, including the identity of beneficial owners.

\begin{tabular}{|l|c|}
\hline \multicolumn{2}{|c|}{ Box 7: KSEI Account Structure (14 February 2012) } \\
\hline \multicolumn{1}{|c|}{ KSEI Participants } & $\begin{array}{l}\bullet \quad \text { Securities Companies (133) } \\
\text { Custodian Banks (20) }\end{array}$ \\
\hline $\begin{array}{l}\text { Securities } \\
\text { Companies }\end{array}$ & \# of sub-accounts: 37539 \\
\hline Custodian Banks & \# of sub-accounts: 341495 \\
\hline & $\begin{array}{l}\text { - Segregated } \\
\text { Account Structure }\end{array}$ \\
& $\begin{array}{l}\text { Total sub-accounts in KSEI: } 379034 \text { (excl. mutual fund } \\
\text { investors) }\end{array}$ \\
\hline \# of SID issued & $\mathbf{3 0 9} \mathbf{9 2 1}$ \\
\hline $\begin{array}{l}\text { Source: M.M. Tong, Investigation and Information about Beneficial Ownership } \\
\text { and Control, Presentation at the OECD-Indonesia Policy Dialogues, Jakarta, } \\
\text { Indonesia, 16 February 2012. }\end{array}$ \\
\hline
\end{tabular}

Besides the existing rules regarding the disclosure of beneficial ownership and control, new rules and practices were recently introduced, marking Indonesia's move to a real "beneficial ownership market". For instance, KSEI recently implemented the requirement to obtain a Single Investor Identity (SID) for each direct investor in the IDX (as stipulated in Bapepam-LK Rule no. V.D.3, which was released on 28 December 2010). The SID enables investors to monitor their shareholdings and buy-sell activities through AKSes, an internet-based system for investors to access KSEl's registration system. With the implementation of the system, KSEI encourages all investors, including ultimate beneficial owners, to obtain an SID. Where does this situate international investors who wish to enjoy tax treaty benefits? They are required to submit a set of documents to the Indonesian Tax Authority which must clearly state if there is another ultimate beneficiary entitled to the fiscal benefits. Even though there is still some uncertainty among investors about the new SID requirement (it is sometimes still viewed as "pointless regulation"), this new development could certainly be viewed as a next step along the path towards a more transparent and reliable capital market in Indonesia. The number of SIDs issued as per 14 February 2012 supports this view (see Box 7).

What is even more important is that capital market institutions, such as KSEI and IDX, already anticipate stricter rules regarding the disclosure of beneficial ownership and control structures. For instance, Bapepam-KL Rule no. IX.C.2 states that an initial public offering prospectus should contain information on the shareholdings of directors, members of the supervisory board and 
shareholders that hold at least $5 \%$ of the outstanding shares of a particular class of stock. To be sure, Rule no. IX.C.2 requires the disclosure of direct shareholders. However in the absence of a change in the law, both Bapepam-LK and IDX increasingly request that companies provide beneficial ownership when they plan an IPO.

Despite these trends, it is acknowledged that it is crucial for the functioning and development of financial markets that clear and transparent requirements for ultimate beneficial owners to disclose their voting and control positions are available. Here the question arises as to which position Indonesia should occupy on the spectrum for beneficial ownership and control rules and regulations (see Box 8). A flexible, principle-based disclosure regime is expected to be more effective in financial markets that are recognised as transparent and sophisticated. A position on the rules-based side makes sense from the perspective of a foreign investor who is not familiar with the ins and outs of the Indonesian capital market. Introducing stringent disclosure rules and regulations complemented with mandatory corporate governance norms could enhance legal certainty and fortify confidence in the market.

Still, determining Indonesia's preferred position on the spectrum is difficult. There is wide consensus among the regulators and other supervisory authorities in the financial market that Bapepam-LK's disclosure rules should be extended to ultimate beneficial owners. These rules should meet internationally accepted standards and explain in detail what should be disclosed, when disclosures should be made and through which channels. According to these international standards, ultimate beneficial owners are formally required to disclose changes in the holding of a class of securities based on the crossings of thresholds starting at $5 \%$ (continuing with intervals of $5 \%$ ) within a reasonable time (not to exceed ten calendar days). The disclosures must be made to the supervisory authority and/or securities commission. ${ }^{50}$ Ideally, information about a substantial ultimate beneficial ownership stake in a listed company must be provided by means of an electronic form. Once filed, this information must be immediately and automatically publically accessible on the website of the supervisory authority and/or securities commission without the need for any action by the supervisory authority or securities commission.

However, it is important that a balance is struck between costs and benefits of the disclosure requirements. There are roughly four categories of costs: (i) unclear and non-transparent rules create confusion and are characterised by non-compliance; (ii) strict disclosure rules may have unintended effects on the listing behaviour of companies; (iii) disproportionate rules could hamper investors' engagement; and (iv) complex and strict disclosure rules, together with limitations on the enforcement capacity of a country, could only add to the mismatch of what a country's legal framework offers and what business practice needs. It is therefore suggested that the concept of substantial beneficial ownership be material, proportionate and sufficiently flexible. Capital markets fare better if the disclosure regime allows "case-by-case" solutions. The reasons for this are that a proportionate regime could help (i) avoid information-overload and confusion in the financial market; (ii) prevent disproportionate compliance costs for the listed companies, their investors and the supervisory authorities, and (iii) capture beneficial owners who seek for de facto control through contractual and informal ownership by adopting new innovative financial products, such as cash-settled derivatives and related techniques.

\footnotetext{
${ }^{50}$ Listed companies should notify the supervisory authority/securities commission of any changes in the share capital of the company, since this could affect the beneficial ownership stake in the company.
} 


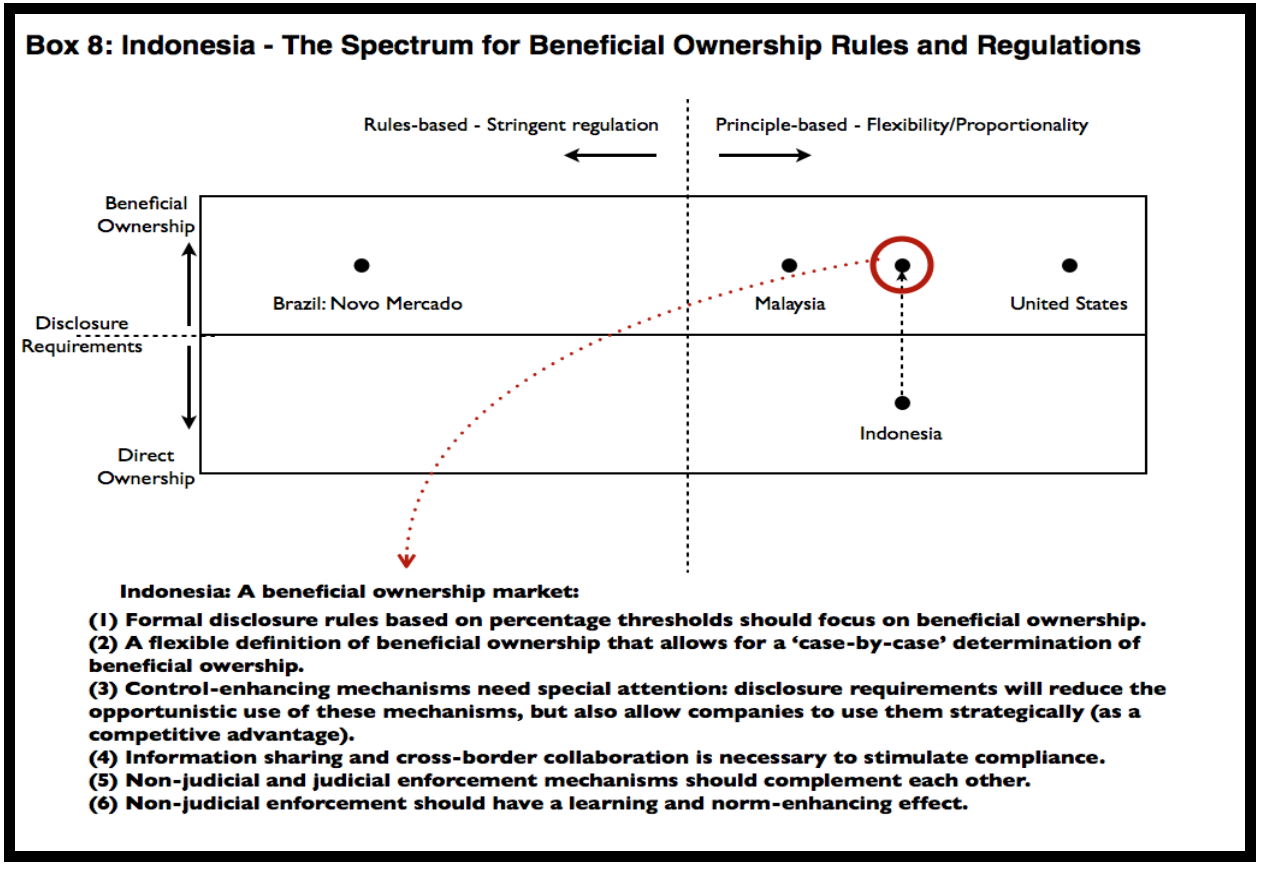

This proportionality principle could be introduced through a flexible definition of beneficial ownership. The following is an outline of a promising approach. Beneficial owners should be defined so as to capture persons who, directly or indirectly, through any contract, arrangement, understanding, one or more intermediaries, or otherwise holds - or is able to acquire, on such owner's own initiative, under a formal agreement or other arrangement - securities which give the owner substantial voting control over the company. In order to increase acceptance of the definition, regulators could explicitly include beneficial ownership arrangements that are commonly used in Indonesia, such as pyramid structures. Regulators should not attempt to introduce an all-encompassing definition. The definition should be sufficiently open to allow regulators (corporate regulator, stock exchange, securities commission and/or supervisory authorities) to take account of technical innovations in financial markets. An open definition has a number of additional advantages. First, it makes it possible for regulators to gradually move towards a full-fledged "beneficial ownership" market without running the risk of (i) putting too much pressure on the Indonesian financial market and (ii) reducing investors' appetite.

Second, a "too-broad" and "too-strict" definition of beneficial ownership would disproportionally increase the costs of regulation. In order to mitigate the negative effects of the introduction of disclosure of beneficial ownership regulation, regulators should consider (besides the introduction of an open definition) exempting certain parties (such as financial institutions holding shares for the sole purpose of clearing and settlement processes and custodians holding shares in solely their custodian capacity) from the disclosure requirement. That is to say that certain parties should not be deemed to be beneficial owners. This could be achieved by the inclusion of safe harbour provisions/exemptions in the definition of beneficial ownership. It should be noted, however, that in order to provide investors with adequate information about the ownership structure of publicly listed companies, it is important that control-enhancing mechanisms, such as the issuance of multiple voting rights shares, but also pyramid structures, are disclosed in the financial statements and on the company's website on a regular basis.

As discussed above, reform that puts Indonesia on the "principle-based" half of the regulatory spectrum will only lead to a more robust capital market for IPOs, which is a critical driver of economic growth, innovation and entrepreneurship. It must be stressed, however, that this 
approach is hardly a panacea. A regulatory regime that functions properly and effectively requires a complete framework in which regulators and other supervisory authorities/gatekeepers in the financial market work together by establishing partnerships. In this regard, the next two Sections of this Report suggest that a two-layer enforcement regime, complemented with domestic and international information sharing arrangements for governmental and nongovernmental agencies, provides excellent opportunities for a constructive dialogue between supervisory authorities/securities commissions, intermediaries and listed companies. This dialogue and sharing of information and experiences is vital to the continuing development of the disclosure system in which market players constantly gain experience and reputation.

\section{Information about beneficial ownership and control}

The effectiveness of the disclosure rules and regulations that were discussed in the previous Section depends largely on the investigation and enforcement capabilities of the regulators, supervisory authorities and/or securities commissions. Indeed, one of the concerns with beneficial ownership and control is that, despite the strict and clear disclosure requirements, a gap between the "rules in the books" and the "application of the rules in practice" leads to (i) distorted information about the true situation regarding beneficial ownership and control, (ii) confusion of the investor community, and (iii) misuse of concealed control positions (Lin Che Wei, 2011). There are two options to bridge the gap and increase compliance with the legislative and regulatory disclosure regime. Regulators and other supervisory authorities could improve the enforcement regime by imposing penalties, such as fines, remedial orders and publicity orders. A more preventive - rather than reactive - approach to increase compliance is the possibility to gather or request information from other governmental and non-governmental agencies that have knowledge about beneficial ownership and control structures. The most obvious sources of information are the central securities depositories, custodians and other financial intermediaries.

\subsection{Central securities depositories, custodians and intermediaries}

As discussed, Bapepam-LK Rule no. V.D.10 contains the "know-your-client" principle. If one of their clients opens a securities account on behalf of a beneficial owner, financial service providers must obtain information about the identity of the beneficial owner. The information must be checked and verified based on documents proving the relationship between the client and the beneficial owner. The Malaysian regulators have introduced an extended "know-your-client" principle. The extensive powers of the Securities Commission in Malaysia to require custodians and authorised nominees and listed companies to provide information about beneficial ownership were already mentioned. The Malaysian Depository Rules clearly state that if a securities account is opened in the name of an authorised nominee, the name of the beneficial owner should be disclosed in a special application form. Moreover, the name of and other relevant information about the beneficial owner must be furnished to the central depository. Here, it is important to add that the information collected by the Securities Commission will only be made publicly available if this is required in the public interest. ${ }^{51}$

In order for the extensive "know-your-client" principle to work properly, regulators (corporate regulator, stock exchange, securities commission and/or supervisory authorities) must collaborate closely and support each other in creating more transparency in the financial market. Apparently, partnerships among regulators are well developed in Malaysia. Without the existence of these partnerships, however, an extensive identification procedure at the level of securities

51 See Vermeulen (2013). Section 45 of the Securities Industry (Central Depositories) Act 1991 (SICDA) provides instances where and the parties to whom such information may be disclosed. 
depositories, custodians and intermediaries could be burdensome and sometimes even not practical. The question that arises here is whether there are alternative sources of information available to regulators, supervisory authorities as well as minority investors who have an interest in pursuing an investigation in the control structures of listed companies when the discussed identification mechanisms fail. In this regard, the rules to protect society against money laundering, terrorist financing and other illicit activities could be considered. Controlling beneficial owners often use domestic and/or offshore corporate vehicles to shield their assets from personal liability, whilst simultaneously hiding their identity. In this regard, anti-money laundering rules that require the disclosure of controlling beneficial owners assist regulators, supervisory authorities and/or minority investors in reconstructing ownership and control structures of listed companies. The next Section analyzes how a legal framework to prevent misuse of corporate vehicles can complement the disclosure regime that applies to listed companies.

\subsection{Disclosure of beneficial ownership of corporate vehicles}

Setting up a chain of corporate vehicles is an effective means to ensure the anonymity of beneficial owners in listed companies. In fact, ownership pyramids or cascades are widely used mechanism to accumulate control power with a relatively limited investment in most countries in the world. These structures enable an individual shareholder to maintain control through multiple layers of ownership while, at the same time, sharing the investment with other (minority) shareholders at each intermediate ownership level. Pyramid structures not only reduce the liquidity constraints of shareholders, but also allows for the retention of substantial voting power. A negative side effect of pyramid structures is the decreasing incentives of controlling investors to monitor management (since they only own a minority of the economic interest in a company).$^{52}$ More worrisome is that the use of a chain of corporate vehicles to conceal the identity of the beneficial owner leads to an increased potential for fraud and tunnelling. It is therefore of utmost importance that the ultimate beneficial owner of the chain of legal entities is identified. An important issue arises when one is forced to deal with a structure comprised of seemingly neverending layers of corporate vehicles. The question that must then be answered is: which individuals are playing "hide-and-seek" behind the corporate veil?

\subsubsection{The shortcomings of anti-money laundering rules}

The anti-money laundering rules may provide an answer. It is generally acknowledged that corporate vehicles are often employed to engage in money laundering, terrorist financing and other illicit activities. In this context, more than 180 jurisdictions have endorsed the International Standards on Combating Money Laundering and the Financing of Terrorism \& Proliferation - the FATF Recommendations (2012) issues by the Financial Action Task Force (FATF), an independent intergovernmental body charged with setting and promoting the implementation of and compliance with standards to effectively combat money laundering, terrorist financing and the financing of proliferation. The FATF Recommendations provided a complete set of principles and standards against money laundering, terrorist financing and the financing of proliferation, which can be flexibly adopted by countries. ${ }^{53}$

For instance, FATF Recommendations (2003) 5 and 12 provide that financial and non-financial professionals must carry out continuous due diligence activities throughout their relationship with

\footnotetext{
52 See Limpaphayom (2011).

53 Recommendations 5 to 12 (Customer Due Diligence and Record-Keeping) and Recommendations 33-34 (Transparency of legal persons and arrangements) play a particularly important role in our search for the identity of the beneficial owner.
} 
clients/customers to (i) identifying their clients/customers and, more importantly, verifying their identities on the basis of information obtained from a reliable source, (ii) identifying and verifying the beneficial owner of a client/customer who is a legal person, trust or similar legal structure, and (iii) report suspicious transactions to the national financial intelligence unit (FIU). Moreover, Recommendations 24 and 25 explicitly require countries to adopt measures that prevent the unlawful use of corporate vehicles and other similar legal arrangements such as trusts. Countries are required to design a legal and institutional framework to ensure that the relevant authorities can have timely access to current and accurate information on the beneficial ownership and control structures of corporate vehicles.

As mentioned above, the FATF Recommendations are recognised as the international standards in the area of anti-money laundering. These Standards are also flexible, because the FATF has adopted a risk-based approach (as opposed to a more detailed rules-based approach), acknowledging that there is no "one-size-fits-all" solution to the prevention of money laundering. The FATF has also drafted a number of supplementary documents that are aimed to assist countries in implementing the Recommendations. To give one example, the due diligence and reporting obligations arising from the Recommendations presented serious challenges to legal professionals. Particularly, the tension between "transparency" (i.e., the reporting obligation of legal professionals that detect or suspect illicit use of corporate vehicles) and "secrecy" (i.e., client confidentiality and lawyer-client privilege) has hampered a smooth implementation of an anti-money laundering framework. The Financial Action Task Force RBA Guidance for Legal Professionals of 2008, which addresses this issue, thus supplements the $40+9$ Recommendations. ${ }^{54}$

\subsubsection{The recommendations of the "Puppet Masters" report}

Considering the foregoing discussion, one would expect that countries increasingly comply with international standards. In theory, it should therefore not be too big a challenge to obtain information about the identity of individuals who beneficially own and control a chain of corporate vehicles. In practice, however, nothing seems further from the truth. A recent report by the World Bank called "The Puppet Masters" shows that compliance with the FATF Recommendations (2003) is disappointing to say the least. ${ }^{55}$ This is reflected in that only $6 \%$ of the evaluated countries are largely compliant with Recommendation 5 of FATF's 40 Recommendations (2003), $53 \%$ of the countries is partially compliant and a significant $41 \%$ is considered to be noncompliant. A closer look at the compliance with recommendations 12,33 and 34 offers a similar view (see Box 9). Even if government authorities, financial intermediaries and other nonfinancial professionals have a legal requirement to obtain, retain and report beneficial ownership, it appears to be difficult to get a complete picture of the beneficial ownership structure of corporate vehicles. Academic research shows that financial and non-financial intermediaries are reluctant to abide by the anti-money laundering rules. ${ }^{56}$ The issues regarding the establishment of a legal entity are a good example: in 35 of the 47 OECD countries, providers of registration services agreed to form shell companies, sometimes even with a bank account, without identifying and verifying the identity of the "beneficial owner".

\footnotetext{
${ }^{54}$ See Vermeulen (2013).

${ }^{55}$ See Van der Does Willebois (2011) and The Economist (2011a).

${ }^{56}$ See Sharman (2011) and The Economist (2011d).
} 


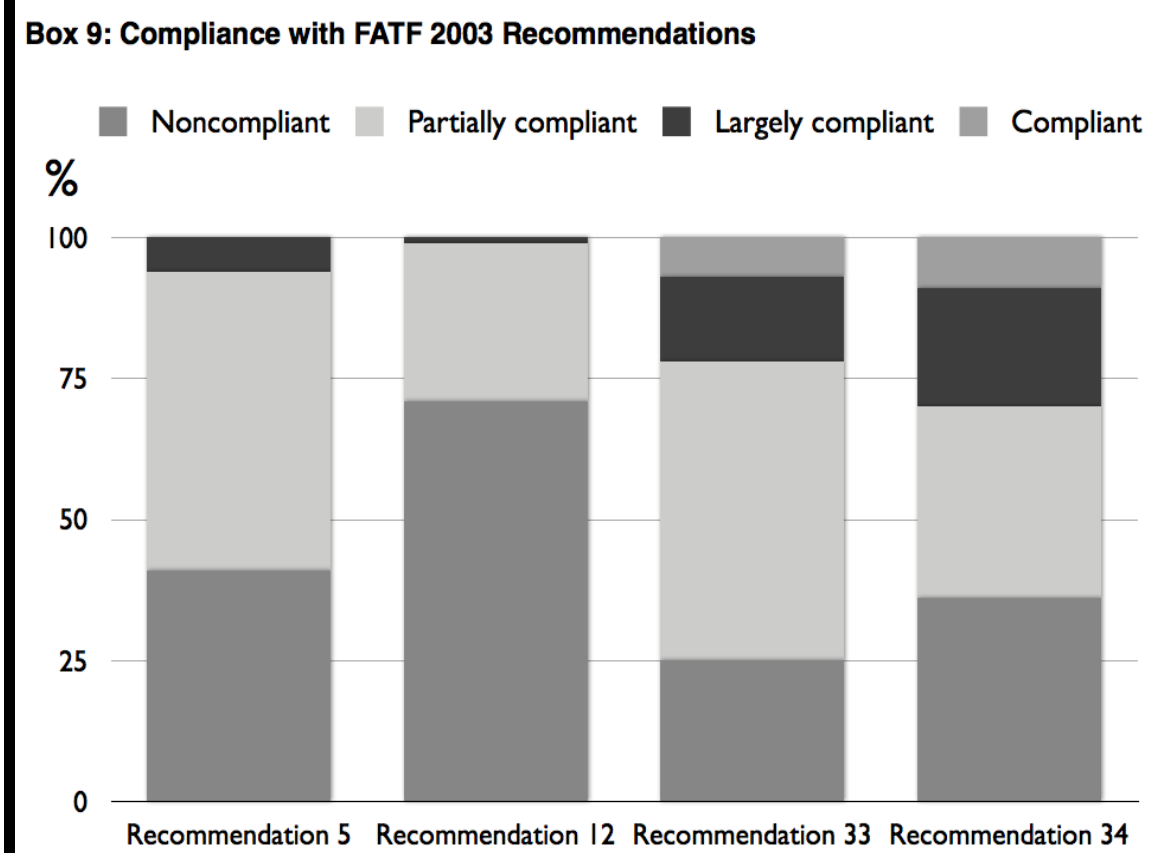

Source: Adapted from The World Bank (by E. Van der Does Willebois et al), The Puppet Masters, How the Corrupt Use Legal Structures to Hide Stolen Assets and What to Do About It, 2011.

Unsurprisingly, the World Bank noted that "there is no lack of theoretical discussion about transparency in the ownership and control of companies", but "the rules as applied in practice" should be dramatically improved. The "Puppet Masters" Report makes a number of recommendations in this regard. The definition of "beneficial ownership" should not necessarily be linked to share ownership. Owning more than a certain percentage of shares certainly gives a meaningful indication of beneficial ownership. However, in identifying the real beneficial owner, the focus should also be on contractual and informal arrangements. The conclusion is similar to that which has been discussed in the previous Section of this Report: the definition of beneficial ownership should be based on two key elements: materiality and flexibility, with a focus on de facto control. Financial and non-financial intermediaries should take the materiality concept to heart when conducting their due diligence. If company registries contain information about beneficial ownership and control structures of corporate vehicles, this information should be kept up-to-date and made available to government authorities, such as supervisory authorities and/or securities commissions, or court-appointed investigators during their investigations. 


\begin{tabular}{|c|c|c|c|c|c|c|}
\hline \multicolumn{7}{|c|}{ Box 10: Corruption and Ease of Doing Business Index } \\
\hline $\begin{array}{c}\text { Ranki } \\
\text { ng }\end{array}$ & Countries & $\begin{array}{c}\text { Companies } \\
\text { in } \\
\text { corruption } \\
\text { cases }\end{array}$ & Countries & $\begin{array}{c}\text { Number of } \\
\text { procedure } \\
\mathbf{s}\end{array}$ & Countries & $\begin{array}{c}\text { Time } \\
\text { (days) to } \\
\text { incorporat } \\
\text { e }\end{array}$ \\
\hline 1 & $\begin{array}{l}\text { United } \\
\text { States }\end{array}$ & 102 & Canada & 1 & $\begin{array}{l}\text { New } \\
\text { Zealand }\end{array}$ & 1 \\
\hline 2 & $\begin{array}{l}\text { British } \\
\text { Virgin } \\
\text { Islands }\end{array}$ & 91 & New Zealand & 1 & Australia & 2 \\
\hline 3 & Panama & 50 & Australia & 2 & Georgia & 2 \\
\hline 4 & $\begin{array}{l}\text { Liechtenstei } \\
\mathrm{n}\end{array}$ & 28 & Georgia & 2 & $\begin{array}{l}\text { Hong Kong } \\
\text { SAR, } \\
\text { China }\end{array}$ & 3 \\
\hline 5 & Bahamas & 27 & $\begin{array}{l}\text { Kyrgyz } \\
\text { Republic }\end{array}$ & 2 & $\begin{array}{l}\text { Macedonia } \\
\text {, FYR }\end{array}$ & 3 \\
\hline 6 & $\begin{array}{l}\text { United } \\
\text { Kingdom }\end{array}$ & 24 & Rwanda & 2 & Rwanda & 3 \\
\hline 7 & $\begin{array}{l}\text { Hong Kong } \\
\text { SAR, China }\end{array}$ & 24 & Slovenia & 2 & Singapore & 3 \\
\hline 8 & Nigeria & 20 & Singapore & 3 & Belgium & 4 \\
\hline 9 & South Africa & 16 & $\begin{array}{l}\text { Hong Kong } \\
\text { SAR, China }\end{array}$ & 3 & Hungary & 4 \\
\hline 10 & $\begin{array}{l}\text { Cayman } \\
\text { Islands }\end{array}$ & 15 & $\begin{array}{l}\text { Macedonia, } \\
\text { FYR }\end{array}$ & 3 & Canada & 5 \\
\hline \multicolumn{7}{|c|}{$\begin{array}{l}\text { Source: Adopted from the World Bank (by E. Van der Does Willebois et al), The Puppet Masters, How the Corrupt Use Legal } \\
\text { Structures to Hide Stolen Assets and What to Do About lt, 2011; World Bank's Doing Business Project } \\
\text { (www.doingbusiness.org). }\end{array}$} \\
\hline
\end{tabular}

Interestingly, the Report emphasises the importance of information in the combat against money laundering and corruption. In this view, financial and non-financial intermediaries should conduct due diligence to gather insights into the ownership and control structures before assisting in the establishment of corporate vehicles. By doing so, they become an adequate source of information at the disposal of capital market regulators and other supervisory authorities. Lawyers who provide legal services beyond the strictly fiduciary or transactional capacity seem to be excluded by the Report. Since corporate vehicles that intend to conduct business activities usually have to open bank accounts, which require the submission of VAT and corporate ID numbers, financial institutions are the most suitable parties to obtain beneficial ownership information.

The Report does not propose any company law reforms that would lead to stricter incorporation requirements. ${ }^{57}$ In a time where company law reforms increasingly enable business parties to set

\footnotetext{
${ }^{57}$ In this context, it is noteworthy that recently US Senators Levin and Grassley started a lobby for the introduction of the "Incorporation Transparency and Law Enforcement Assistance Act". Under this proposal, the incorporation of corporate vehicles in the United States would require the collection and retention of identity information for beneficial owners (names, addresses, driver's license or passport number) of corporations and limited liability companies (LLCs).
} 
up corporate vehicles without the intervention of professionals, such proposals would have easily been construed as not being useful, only increasing red tape and hampering entrepreneurship and economic growth. Box 10 seems to indicate that there is no direct correlation between the ease of setting up a corporate vehicle with a business (measured on the number of procedures and days needed to start a business) and the chance of corporate vehicles being involved in corruption cases. The countries that incorporated most "corrupted" corporate vehicles (including trusts and other company forms) do not top the World Bank's "starting a business" ranking. Looking at the top-10 positions (corruption cases, number of procedures to start a business and time to start a business), Hong Kong is the only country that appears in all rankings. Interestingly, some countries where it is very easy to incorporate your business (Australia, Canada, New Zealand and Singapore) have top-10 positions (meaning they are perceived to be among the 10 least corrupt countries) in the Corruption Perception Index 2011, which ranks countries based on how corrupt their public sector is perceived to be.

\subsubsection{The FATF recommendations (2012)}

It follows from the above discussion that devising and maintaining a legal system that ensures the accurate and timely disclosure of beneficial ownership and control structures is a daunting task. Existing systems should be revisited periodically, and the FATF published its revised FATF Recommendations in February 2012. ${ }^{58}$ The FATF Recommendations (2012) took into account the World Bank's Puppet Masters Report, and contain, among other things, measures that are expected to significantly improve transparency regarding beneficial ownership structures. For instance, the 2012 Recommendations encourage countries to implement stricter rules and regulations that require companies or company registries to obtain and hold up-to-date information on the companies' beneficial ownership, or to have other comparable measures to ensure that such information is readily available. The FATF acknowledges that the implemented measures should be proportionate to the level of risk and/or complexity related to the use of beneficial ownership structures. By incorporating the "principle of proportionality" in the Recommendations, the FATF significantly reduces the cost of regulation, while at the same time increasing compliance.

Transparency proponents may argue that the revised Recommendations do not go far enough. They view the "principle of proportionality" as a serious obstacle to the implementation of the stricter Recommendations in practice. ${ }^{59}$ These responses suggest that the overall acceptance of the revised disclosure regime would be significantly higher if FATF puts more pressure on governments. But there are other ways to improve acceptance of legal rules and requirements. One of those ways is to encourage collaboration and information exchange between relevant regulators, supervisory authorities and private companies. FATF rightly puts emphasis on both national and international co-operation in relation to obtaining beneficial ownership information. The next Section of the Report gives examples of successful collaboration strategies.

\subsection{Intra-governmental and cross-border collaboration and information sharing}

If information about beneficial ownership in corporate vehicles becomes increasingly important in combating illicit activities, such a system stands or falls with the possibility for supervisory authorities, securities commissions and the like, to gain access to this information. Reforms in this area are geared towards the improvement of intra-governmental collaborations to not only obtain and maintain accurate information about beneficial ownership of corporate vehicles, but

\footnotetext{
${ }^{58}$ A revised set of the 40 Recommendations is issued in February 2012. See FATF (2012b).

${ }^{59}$ See Binham (2012).
} 
also to collectively detect and deter money laundering and tax evasion. In this respect, two different initiatives in Singapore and Australia are worth mentioning.

Singapore's Accounting and Corporate Regulatory Authority (ACRA) streamlined its company registration system and made it user-friendly by creating a one-stop business services portal (BizFile). The most important feature of the system is that government agencies are able to access secure information by simply obtaining a BizFile subscription. The web-based system can provide tailor-made information packages, thus eliminating unnecessary costs caused by going through irrelevant information, thereby reducing the risks of an information-overload. ${ }^{60} \mathrm{~A}$ webbased information system encourages intra-governmental collaborations.

Intensifying these collaborations has also been very successful in Australia under the name of Project Wickenby. This Project is a multi-agency task force that was formed in 2006 with an aim to protect the integrity of Australian financial and regulatory systems. It has been very successful as demonstrated by "more than $\$ 1.1$ billion in liabilities raised, as well as increased tax collections from improved compliance behaviour by participating taxpayers". 61 The task force combines the powers of several government agencies and authorities to conduct investigations, audits and prosecutions. Although the multi-agency collaboration has mostly focused on the fight against tax evasion, avoidance and crime, it arguably helps in reducing the illicit use of corporate vehicles. Activities under project Wickenby, such as civil investigations conducted by the Australian Securities and Investments Commission (ASIC), also help provide a clearer picture about beneficial ownership arrangements. If needed, the task force calls upon the assistance of governments and organisations around the world to jointly combat illicit activities.

Indeed, encouraging information sharing among government agencies at a national level is not sufficient. The internationalisation of and innovations in financial markets make it necessary to intensify the collaboration among national securities regulators and other enforcement bodies. Due to the fact that foreign ownership in domestic stock markets is increasing, there is an urgent need for information exchange on a global scale. To facilitate this, associations have emerged to set up and encourage international co-operation in developing and promoting cross-border exchange of information. One example is the International Organization of Securities Commissions (IOSCO). IOSCO offers an important benchmark to assist national regulators in their efforts to develop an efficient and transparent securities market. The IOSCO Principles also contain recommendations to mutually increase international co-operation and the sharing of both public and non-public information among regulators. ${ }^{62}$

If financial markets are becoming increasingly internationally oriented and complex, then the introduction of information sharing provisions in the national laws and regulations is likely to further stimulate cross-border co-operation in the enforcement of rules that are designed to protect the interests of minority investors and other stakeholders in listed companies. Section

\footnotetext{
60 See Van der Does Willebois (2011).

${ }^{61}$ See Australian Government (n.d.) and Palmer (2011).

62 IOSCO encouraged the implementation of these recommendations by having adopted a multilateral memorandum of understanding (IOSCO MMoU) specifically designed to facilitate the cross-border enforcement and information exchange among its signatories. The terms of the IOSCO MMoU facilitate the exchange of information and records about the identity of beneficial owners of listed companies and other corporate vehicles (see Paragraph 7 of the IOSCO MMoU). In this respect, the IOSCO MMoU arguably plays an important role in a country's enforcement regime in that it ensures that investors have access to accurate, timely and cross-border beneficial ownership information. The next Section focuses on the public and private enforcement mechanisms, including the possibilities to exchange information that may exist on a country level.
} 
150(2) of the Malaysian Securities Commission Act 1993, which provides that the Securities Commission may, upon receiving a written request from a foreign supervisory authority for assistance to provide information about an alleged breach of a legal or regulatory requirement, offer assistance to the foreign supervisory authority by carrying out investigations of the alleged breach of the legal or regulatory requirement or provide such other assistance to the foreign supervisory authority as the Securities Commission sees fit. National legal rules that encourage information sharing on an international scale encourage mutual recognition and establish mutual reciprocity and collaboration among national supervisory authorities.

\subsection{Indonesia: The next steps}

Information about the beneficial ownership and control structures of listed companies is an important element in a country's corporate governance framework. As discussed, a clear picture of who owns and controls listed companies is necessary to reduce opportunistic and self-dealing behaviour. A corporate governance framework can only be effective if supervisory authorities and investors know the identity of the controlling owners of a company. The first and most important source of information is the investor who discloses his/her ownership/control position under the disclosure rules and regulations. Compliance with these rules and regulations is crucial.

This Section contains two broad policy options to stimulate compliance and prevent noncompliance. Information is key. First, countries should improve the regulatory framework to detect and deter misuse of chains of corporate vehicles that are often employed to conceal a beneficial owner's identity and intentions. Following the recommendations of the World Bank report "The Puppet Masters" as well as the revised FATF Recommendations (2012), the financial and non-financial intermediaries should widen their due diligence and verify the identity of ultimate beneficial owners who materially control a company or chain of companies. Second, and perhaps more importantly, countries should identify and develop improvements in information sharing arrangements on both a national and international level. Government agencies, such as supervisory authorities and securities commissions, financial services providers and other public and private organisations can combat the misuse of corporate vehicles more effectively by closely working together and setting up national electronic systems that facilitate the sharing of information concerning beneficial ownership structures, including the identity of the individuals who are ultimately in control of chains of companies. Since beneficial owners may seek to avoid detection by using corporate vehicles in other jurisdictions, it is crucial that a country's legal and regulatory disclosure regime supports and encourages international collaborations, such as the adoption of IOSCO's multilateral memorandum of understanding and a clear implementation of FATF's Recommendations regarding the compliance with anti-money laundering standards. ${ }^{63}$

Recently, the FATF identified Indonesia as one of the jurisdictions that have several deficiencies in their anti-money laundering regime. It was noted that despite the fact that Indonesia has made significant progress in improving its regime (for instance by enacting anti-money laundering legislation in 2010), its future focus should be on the practical implementation of the measures. ${ }^{64}$

\footnotetext{
${ }^{63}$ The Global Forum on Transparency and Exchange of Information for Tax Purposes conducts peer reviews to assess a country's ability to co-operate and share information with other tax authorities. As for Indonesia, the Global Forum has recently conducted a review process which examines both the legal and regulatory aspects of the exchange of information (Phase 1 review). This Phase 1 review report was published on 26 October 2011. The Global Forum reviews, among other things, the access to ownership and identity information. It is therefore of utmost importance that not only tax authorities, but also other supervisory and regulatory authorities (such as Bapepam-LK) take note of the recommendations. In the first half of 2013, a Phase 2 review is scheduled. The Global Forum will then review the exchange of information in practice.
}

${ }^{64}$ See FATF (2012a). 
Arguably, Indonesian regulators should intensify their collaboration efforts in order to improve compliance. Not only would constructive dialogue and collaboration lead to more accurate and timely information about beneficial ownership and control structures, it would also avoid the implementation of complex and sometimes even inconsistent rules and regulations.

Several reforms to improve transparency in the financial market, initiated by KSEI, IDX and Bapepam-LK, were already mentioned in the first Section of the Report. These reforms were the result of some collaborative actions. However, the collaboration should be taken one step further to ensure that beneficial owners have the right incentives to be transparent about their shareholdings. For example, the regulators in Indonesia are well aware of the fact that transparency in the capital market leads to more liquidity. In order to improve a stock's liquidity even further, fiscal measures were taken to increase the free float - shares that are freely tradable on IDX. Companies that maintain a free-float of at least $40 \%$ were rewarded with tax benefits. The rationale behind the tax measures is clear: tax benefits provide companies with a high-powered incentive to increase their shareholder base, while at the same time reducing the power of controlling beneficial owners. In the context of Indonesia, however, these tax incentives arguably have a detrimental effect on the transparency of ownership and control structures of listed companies. For instance, beneficial owners who own more than $60 \%$ of the shares of a company through pyramid structures and cross-shareholdings will be discouraged to disclose their actual ownership if this would lead to a loss of benefits under the tax regime. The decision not to disclose would be the rational answer here. By not disclosing the company's control structure, the company and its owners can at least keep up the appearance that the free float requirement is complied with, thereby enjoying the beneficial fiscal treatment.

The goal of this Section has been to show that the effectiveness (and practical acceptance) of the disclosure rules and regulations will increase if regulators and other supervisory authorities share information and collaborate. Information sharing and collaboration go beyond increasing access to beneficial ownership information. A periodical and structured dialogue among regulators will also lead to more consistent and sustainable rules and regulations. Yet, international collaboration and information sharing arrangements are not enough. Disclosure rules and regulations can only work effectively if they can be enforced in practice. The next Section will offer a framework for an enforcement system that not only increases compliances, but also encourages dialogue between regulators, companies and beneficial owners.

\section{Enforcement}

As already mentioned in the previous Section, information sharing arrangements in the area of beneficial ownership and control are most likely not sufficient to completely close the gap between the disclosure rules in the books and the application of the rules in practice. For a disclosure regime to be effective, it is also important to devote adequate resources to the development of an enforcement system that ensures the compliance with and accuracy of the disclosed and gathered information. Policy makers and regulators should take three key factors into account when devising enforcement mechanisms: ${ }^{65}$ (i) integrity and speed are pivotal to every enforcement system; (ii) the system should reflect a balanced mix of judicial and nonjudicial procedures; and (iii) regulators and other supervisory authorities should develop experience in determining the relevance and impact of a particular case. Considering these factors, this Section proposes a two-layer enforcement system. The first layer consists of nonjudicial enforcement mechanisms. The second layer takes a more formalistic approach and is viewed as a last resort.

\footnotetext{
${ }^{65}$ The key factors are derived from Enriques (2002). See also Vermeulen and Zetzsche (2010).
} 


\subsection{Non-judicial enforcement}

Non-judicial enforcement mechanisms, such as "information requests", norm-enhancing reprimands and public disclosure of non-compliance, play an important role in the enforcement of the disclosure rules and regulations regarding beneficial ownership and control structures. The informality of the mechanisms makes it possible for regulators and supervisory authorities, which are usually understaffed and tend to work under budget constraints, to economise on the costs of administrative proceedings that may lead to the imposition of formal sanctions, such as fines and share transfer restrictions. ${ }^{66}$ It is therefore not surprising that supervisory authorities/securities commissions usually prefer to follow the non-judicial enforcement route and impose informal sanctions (see Box 11).

What is more important in the context of this Report is that non-judicial enforcement provides the opportunity to respond quickly and, hence, often more effectively to non-compliance. Additionally, informal sanctions bring supervisory authorities and/or securities commissions closer to the market and business community. Evidently, this is beneficial as it stimulates dialogue with the business community, which, in turn, adds to the experience level of regulators and supervisory authorities. Several reasons suggest that non-judicial enforcement forms an effective means to manage non-compliance with disclosure and reporting rules and regulations in a globalising and increasingly complex world. In particular, non-judicial enforcement holds out the possibility of better detecting beneficial ownership and control structures that fall in the grey area of the applicable rules and regulations (such as contractually acquired ownership and control structures). Moreover, the informal approach and co-operative environment offer a variety of softer mechanisms to manage specific problems, leading to a higher level of compliance with the spirit of the disclosure requirements.

Although not directly related to the disclosure of beneficial ownership, an example of a welldeveloped non-judicial system can be found in the United States. The staff of the SEC's Division of Enforcement selectively reviews filings made under the Securities Act and the Exchange Act to monitor and enhance compliance with the applicable disclosure and accounting requirements. In this regard, the SEC constituted the Delinquent Filings Program to ensure the sufficiency, adequacy, and timeliness of required disclosures. Under this Program, delinquency notice letters may be sent to listed companies that have failed to make the required filings to spur them to promptly comply with their reporting obligations. These letters normally state that non-compliance may lead to suspension or revocation of the registration of the securities, and possibly a trading suspension of up to 10 business days. These sanctions will be imposed if the SEC determines that such actions are authorised and appropriate under the law.

\footnotetext{
${ }^{66}$ See Armour (2008).
} 


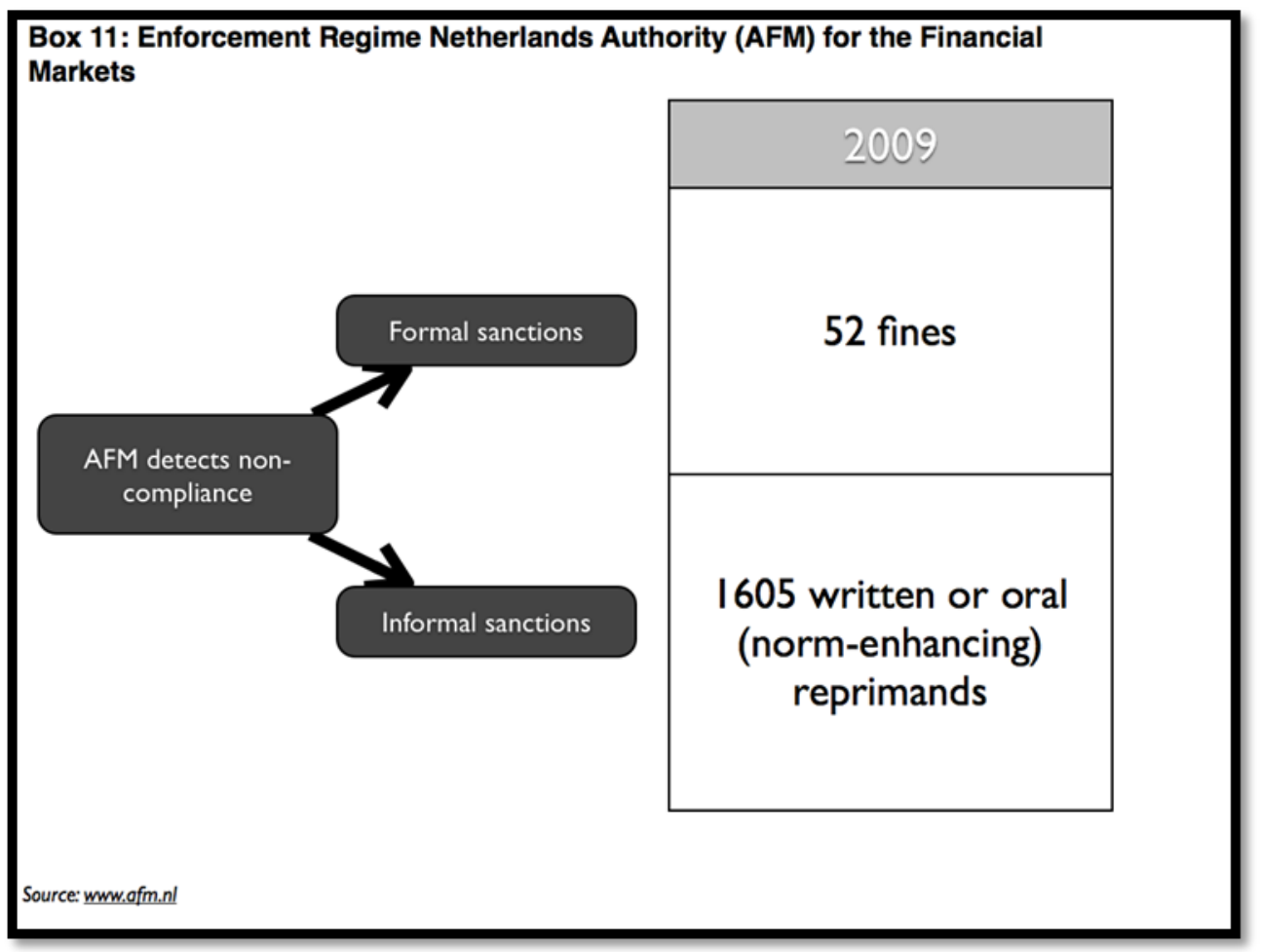

\subsection{Judicial enforcement}

The second layer of the enforcement system consists of more formal mechanisms, such as fines, suspension of voting rights, restrictions of share transfers and sometimes even imprisonment sanctions. The formal sanctions are usually imposed following a judicial or administrative procedure. In Malaysia, the judicial enforcement mechanisms are typically made up of fines or imprisonment or both. For instance, the Securities Commission is empowered to impose a penalty in proportion to the severity or gravity of the breach on the person in breach subject to a cap of RM500 000, if a person is in default in complying with the provisions of the Capital Market \& Services Act 2007 or any other securities laws; or fails to comply with the rules of the stock exchange, written notice, guidelines issued or condition imposed by the Securities Commission.

As the Securities Commission may also invoke a number of informal measures, it could very well be argued that the formal measures should be viewed as a "last resort". Before imposing formal penalties, the Securities Commission may prefer to (i) direct the person in breach to comply with, observe, enforce or give effect to such rules, provisions, written notice, condition or guideline or (ii) reprimand the person in breach. As mentioned, the speed and flexibility of the non-judicial procedures are attractive measures for listed companies and their investors. Not only do they benefit - from a cost standpoint - from lower compliance costs, but they also benefit from the inducement to settle defaults in a more informal setting. However, as the Malaysian example shows, non-judicial public enforcement measures do not make more formal enforcement mechanisms obsolete and superfluous. The informal approach does not work properly without the possibility of imposing formal mechanisms.

The interplay between non-judicial and judicial measures is reflected in Box 12, which shows how the two layers of enforcement combine in Malaysia. By virtue of the powers provided to it by the Listing Requirements, Bursa Securities may, for instance, impose non-judicial enforcement sanctions such as submitting a formal request to obtain documents for investigation purposes 
from the listed companies. In the event that companies remain non-compliant with the Listing Requirements, Bursa Securities may take or impose any actions or penalties as it considers appropriate. Bursa Securities is required to notify the Securities Commission of its decisions which may include the issuance of a caution letter, private reprimand, public reprimand, or letters requiring compliance. It should be noted that the imposition of any one or more of the actions or penalties set out the Listing Requirements does not preclude Bursa Securities from later taking or imposing such further actions or penalties against a listed company, as Bursa Securities sees fit. $^{67}$

\begin{tabular}{|l|l|}
\hline \multicolumn{2}{|c|}{ Box 12: Enforcement in Malaysia } \\
\hline $\begin{array}{l}\text { Non- } \\
\text { Judicial }\end{array}$ & $\begin{array}{l}\text { Listing Requirements - caution letters / reprimands } \\
\text { Capital Markets \& Services Act 2007- official directions / reprimands }\end{array}$ \\
\hline Judicial & $\begin{array}{l}\text { Malaysian Companies Act 1965 - failure to comply with substantial } \\
\text { shareholders requirement: } \\
\text { restrictions } \\
\text { Capital Markets \& Services Act } 2007 \text { - breach of disclosure requirement may } \\
\text { lead to a fine or even imprisonment }\end{array}$ \\
\hline $\begin{array}{l}\text { Source: Adopted from E.P.M. Vermeulen, Beneficial Ownership and Control: A Comparative } \\
\text { Study, OECD (2012). }\end{array}$
\end{tabular}

\subsection{Indonesia: The next steps}

A well-functioning disclosure regime should be supplemented with a mix of non-judicial and judicial mechanisms that encourage beneficial owners to effectively make disclosures and inform the company, other investors and the market about the beneficial ownership and control structure and their intentions. The implementation of a two-layer enforcement approach has the additional benefit that Indonesia can move gradually towards a fully-fledged beneficial ownership market. The implementation of an open definition of beneficial ownership has a similar effect. Examples from other jurisdictions have indicated the effectiveness of the interplay between non-judicial mechanisms, such as "information requests" and reprimands, and more formal judicial measures, such as fines and non-financial penalties. There is at least a suspicion that the non-judicial aspect of the enforcement system is more effective in dealing with complex and innovative investment structures pursued by beneficial owners than direct formal judicial intervention.

A two-layer enforcement system can be cost-effective, reduces burdens on regulators, provides significant learning opportunities for regulators and, most importantly, offers speedy and effective norm-enhancing mechanisms. Companies and their beneficial owners will arguably have fewer incentives to make costly efforts to block reforms if formal sanctions are viewed as a last resort. The question remains, however, how a two-layer system could increase the compliance by foreign or quasi-foreign investors. The question is especially important since beneficial owners often employ foreign corporate vehicles in their pyramid structures. Remarkably, according to recent data, $60 \%$ of the investments in the Indonesian capital market come from foreign investors. ${ }^{68}$ It is thus - as seen in Section 3.4 - important that regulators and supervisory authorities in Indonesia set up strong co-operative relationships with their foreign counterparts. One way to do this is to rely on the introduction of regulatory provisions in the laws of Indonesia which unilaterally encourage Bapepam-LK and other supervisory authorities to assist their foreign

\footnotetext{
${ }^{67}$ See Paragraphs 16.18 and 16.19 of the Listing Requirements.

${ }^{68}$ See Thamrin (2012).
} 
counterparts in their investigation and enforcement efforts in Indonesian investors. These unilateral mechanisms encourage mutual recognition and establish mutual reciprocity and collaboration among supervisory authorities on an international level. ${ }^{69} \mathrm{It}$ is only to be expected that the possibility of co-operation and information exchange will increase in a non-judicial, more informal, setting.

${ }^{69}$ The Cayman Islands, for instance, has implemented provisions in its laws that enable governmental authorities to exchange information unilaterally on request, in all tax matters, with 12 jurisdictions. It may extend this unilateral mechanism to other "Scheduled Countries". See OECD (2010).

${ }^{70}$ For instance, informal co-ordination of investigations is relatively common in international cartel cases. See Low (2012). 


\section{BIBLIOGRAPHY}

Armour, J. (2008), "Enforcement Strategies in UK Corporate Governance: A Roadmap and Empirical Assessment", ECGI - Law Working Paper No. 106/2008.

http://dx.doi.org/10.2139/ssrn.1133542 and Armour, J. and J. Payne, J. (eds). (2009), Rationality in Company Law: Essays in Honour of Dan Prentice, Hart Publishing, Oxford.

Australian Government (n.d.), www.ato.gov.au/content/00220075.htm.

Bebchuk, L. A. and R. J. Jackson (2012), "The Law and Economics of Blockholder Disclosure", Harvard Law and Economics Discussion Paper No. 702, Harvard Business Law Review, Vol. 2, No. 1, pp. 40-60 and Columbia Law and Economics Research Paper No. 405. http://dx.doi.org/10.2139/ssrn.1884226.

Brazil: Excellence in Securities Transactions (BEST) (n.d.), Brazil Market Profile, www.bestbrazil.org.br, accessed in November 2011.

Binham, C. (2012), "Banks urged to report suspected tax crime", Financial Times, 16 February.

Black, B. S. and R. J. Gilson (1998), "Venture capital and the structure of capital markets: Banks versus stock markets", Journal of Financial Economics 47. http://dx.doi.org/10.1016/S0304405X(97)00045-7.

Deutsche Börse Group (2011a), "Banking Market Profile - Brazil", 21 January, Clearstream Banking Luxembourg, Luxembourg, www.clearstream.com.

Deutsche Börse Group (2011b), "Guide to Disclosure Requirements", 3 August, Clearstream Banking Luxembourg, Luxembourg, www.clearstream.com.

Di Miceli da Silveira, A. (2010), Corporate Governance and Capital Markets in Brazil - History and Current Overview, Presentation, December.

Enriques, L. (2002), “Do Corporate Law Judges Matter? Some Evidence from Milan”, European Business Organization Law Review, 3, pp 765-821, doi:10.1017/S1566752900001142.

Enriques, L., M. Gargantini and V. Novembre (2011), "Mandatory and Contract-Based Shareholding Disclosure", Uniform Law Review / Revue de Droit Uniforme, pp. 713-742, http://ssrn.com/abstract=1807047.

European Commission (2011), "Impact Assessment", Report from the Commission Commission Staff Working Paper, SEC(2011) 1279 final/2.

Financial Action Task Force (FATF) (2012a), FATF Public Statement, 16 February, www.fatfgafi.org/document/18/0,3746, en $32250379322369924969473811111,00 . \mathrm{html}$. 
Financial Action Task Force (FATF) (2012b), International Standards on Combating Money Laundering and the Financing of Terrorism \& Proliferation - the FATF Recommendations, 16 February, www.fatf-gafi.org/recommendations.

Gilson, R. J., H. Hansmann and M. Pargendler (2010), "Regulatory Dualism as a Development Strategy: Corporate Reform in Brazil, the U.S., and the EU", Stanford Law and Economics Olin Working Paper No. 390; Columbia Law and Economics Working Paper No. 368; Yale Law \& Economics Research Paper No. 399; ECGI - Law Working Paper No. 149/2010; Rock Center for Corporate Governance at Stanford University Working Paper No. 80, http://dx.doi.org/10.2139/ssrn.1541226.

Gorga, É. (2009), "Changing the Paradigm of Stock Ownership from Concentrated Towards Dispersed Ownership? Evidence from Brazil and Consequences for Emerging Countries", Northwestern Journal of International Law \& Business, Vol. 29, http://ssrn.com/abstract=1689103.

Gorga, É. and S. T. Mascarenhas (2010), "Venture Capital Ownership and Contracting During the Brazilian IPO Boom", Working Paper, Getulio Vargas Foundation Law School at Sao Paulo (DIREITO GV), http://dx.doi.org/10.2139/ssrn.1641540.

Kamar, E., P. Karaca-Mandic and E .L. Talley (2008), "Going-Private Decisions and the Sarbanes-Oxley Act of 2002: A Cross-Country Analysis", USC Center in Law, Economics \& Organization Research Paper No. C06-5, USC Law Legal Studies Paper No. 06-10; UC Berkeley Public Law Research Paper No. 901769, http://ssrn.com/abstract=901769.

Katz, D. A. and L. A. McIntosh (2012), "Section 13(d) Reporting Requirements Need Updating", New York Law Journal.

Kenny, C. (2011), Bloomberg Business Week, Opening Remarks, Small Isn't Beautiful, 3 October.

Licht, A. N. (2000), "The Mother of All Path Dependencies: Toward a Cross-Cultural Theory of Corporate Governance Systems", Delaware Journal of Corporation Law 26, http://dx.doi.org/10.2139/ssrn.208489.

Limpaphayom, P. (2011), "The Effect of Ownership Structure on the Relation between Corporate Governance and Firm Value in Thailand", Presentation, OECD-Indonesia Policy Dialogue:

Disclosure of Beneficial Ownership and Control, Bali, 5 October.

Lin Che Wei (2011), "Misuse of Corporate Vehicles for Illicit Purposes", Presentation, OECDIndonesia Policy Dialogue: Disclosure of Beneficial Ownership and Control, Bali, 5 October.

Low, D. M. (ed.) (2012), "Cartel Regulation 2013”, Getting the Deal Through, Global Competition Review.

McCahery, J. A. and E. P. M. Vermeulen (2011), "The Case Against Reform of the Takeover Bids Directive”, European Business Law Review, v.22, no.5.

Mendoza, J. M. (2007), "Securities regulation in low-tier listing venues: The rise of the Alternative Investment Market", Fordham Journal of Corporate \& Financial Law, v.13, issue 2. 
Mendoza, J. M. and E. P. M. Vermeulen (2011), "The "New" Venture Capital Cycle: The Emergence of Alternative Liquidity Options", in The European Financial Market Transition (H.S. Birkmose, M. Neville and K. Engsig Sørensen eds.), Kluwer Law International, London.

Mendoza, J. M., C. F. Van der Elst and E. P. M. Vermeulen (2010), "Entrepreneurship and Innovation, The Hidden Costs of Corporate Governance in Europe", South Carolina Journal of International Law \& Business 7.

OECD (2000), OECD Small and Medium Enterprise Outlook 2000, OECD, Paris.

OECD (2001), Behind the Corporate Veil: Using Corporate Entities for Illicit Purposes, OECD Paris, www.oecd.org/daf/ca/behindthecorporateveilusingcorporateentitiesforillicitpurposes.htm.

OECD (2009), Corporate Governance and the Financial Crisis: Key Findings and Main Messages, OECD, Paris. www.oecd.org/corporate/ca/corporategovernanceprinciples/43056196.pdf.

OECD (2010), Global Forum on Transparency and Exchange of Information for Tax Purposes, Peer Review Report, Phase 1, Legal and Regulatory Framework, Cayman Islands, OECD, Paris.

www.oecd.org/fr/pays/caimanesiles/peerreviewreportofcaymanislandsphase1legalandregulatoryframework.htm.

OECD (2011), Reform Priorities in Asia: Taking Corporate Governance to a Higher Level, OECD, Paris. www.oecd.org/daf/ca/49801431.pdf.

Palmer, B. (2011), Misuse of Corporate Vehicles for Illicit Purposes, Australian Experience, Presentation, OECD-Indonesia Policy Dialogue: Disclosure of Beneficial Ownership and Control, Bali, 5 October.

Pistor, K. and C. Xu (2003), "Fiduciary Duties in (Transitional) Civil Law Jurisdictions - Lessons from the Incompleteness of Law Theory", in Mildhaupt, C. (ed.), Global Markets, Domestic Institutions: Corporate Governance in a New Era of Cross-Border Deals, Columbia University Press, New York.

Romano, R. (2012), "Regulating in the Dark", Yale Law \& Economics Research Paper No. 442, http://dx.doi.org/10.2139/ssrn.1974148.

Santana, M. H. (2012), presentation during the Exploratory Roundtable on Corporate Governance, Innovation and Value Creation, Capital Markets Board of Turkey and the OECD, Istanbul, Turkey, 1 February.

Santana, M. H., M. Ararat, P. Alexandru, B.B. Yurtoglu and M. Rodigues da Cunha (2008), Novo Mercado and Its Followers: Case Studies in Corporate Governance Reform, Global Corporate Governance Forum and International Finance Corporation.

Securities Commission Malaysia (2010), 2010 SC Annual Report, www.sc.com. $\mathrm{my} / \mathrm{main}$.asp?pageid=381\&linkid=2806\&yearno=2010\& mod=paper. 
Sharman, J. C. (2011), The Money Laundry: Regulating Criminal Finance in the Global Economy, Cornell University Press.

Skinner, A. (2011), "Commercial code: New law puts emphasis on transparency", 13 December, The Financial Times Ltd, London, http://www.ft.com/intl/cms/s/0/02ae6e00-20f1-11e18133-00144feabdc0.htm|\#axzz2Xy3oZ3IG.

Smith, R. (2011), One Share, One Vote? Groupon and Zynga Founders Get Extra Clout Before IPOs, The Wall Street Journal, 28 October.

Thamrin, N. M. (2012), Sub-Custody and Clearing 2012, Presentation at the OECD-Indonesia Policy Dialogues, Jakarta, Indonesia, 16 February.

The Economist (2011a), "Corruption, Grand schemes", 29 October, The Economist Newspaper Limited, London, www.economist.com/node/21534761.

The Economist (2011b), "Pointless regulations, It's a jungle out there", 22 October, The Economist Newspaper Limited, London, www.economist.com/node/21533395.

The Economist (2011c), "Schumpeter, Big and clever", 17 December, The Economist Newspaper Limited, London, www.economist.com/node/21541826.

The Economist (2011d), "Undeclared beneficial ownership, License to loot”, 17 September, The Economist Newspaper Limited, London, www.economist.com/node/21529021.

The Economist (2012), "The Dodd-Frank act: Too big not to fail”, 18 February, The Economist Newspaper Limited, London, http://www.economist.com/node/21547784.

The World Bank (2006), Unlocking Indonesia's Domestic Financial Resources: The Role of NonBank Financial Institutions, December.

The World Bank (2010), Report on the Observance of Standards and Codes (ROSC), Corporate Governance Country Assessment: Indonesia, April, http://www.worldbank.org/ifa/rosc cg idn 2010.pdf.

US Department of the Treasury (2011), the IPO Task Force, Rebuilding the IPO On-Ramp, Putting Emerging Companies and the Job Market Back on the Road to Growth, 20 October.

Van der Does Willebois, E. et al (2011), The Puppet Masters, How the Corrupt Use Legal Structures to Hide Stolen Assets and What to Do About It, The World Bank.

Vermeulen, E. P. M. (2011), Shopping for Jurisdictions (What Do Venture-Backed Companies in Initial Public Offerings Teach Us?), ICGN (International Corporate Governance Network) 2011 Conference - Corporate Governance Change in the Americas, Miami, Florida, USA, December.

Vermeulen, E. (2013), "Beneficial Ownership and Control: A Comparative Study - Disclosure, Information and Enforcement", OECD Corporate Governance Working Papers, No. 7, OECD Publishing. doi: 10.1787/5k4dkhwckbzv-en. 
Vermeulen, E. P. M. and D. A. Zetzsche (2010), "The Use and Abuse of Investor Suits - An Inquiry into the Dark Side of Shareholder Activism", European Company and Financial Law Review 7.

Whipp, L. (2011), Japan tightens M\&A rules after Olympus, the Financial Times, 16 December.

Wu Xun (2005), "Political Institutions and Corporate Governance Reforms in Southeast Asia", in Ho Khai Leong (ed.), Reforming Corporate Governance in Southeast Asia, Economics, Politics, and Regulations, Institute of Southeast Asian Studies. 
www.oecd.org/daf/corporateaffairs/wp 